\title{
Flamenco, trovo y cante de las minas
}

\author{
José F. Ortega \\ Universidad de Murcia
}

Enviado: $01-11-2020$

Aceptado: 03-12-2020

\section{Resumen}

El mundo del trovo de la Sierra Minera de Cartagena-La Unión está íntimamente ligado al devenir de los cantes de las minas: se considera, de hecho, una de las fuentes nutricias del repertorio de letras del cante minero. En este artículo se traen a colación algunas de las más conocidas, así como otras creadas por troveros en su rol como poetas. Se recuerdan también algunas de las melodías de malagueña utilizadas en las veladas troveras, así como ciertos estilos flamencos ligados a nombres de troveros míticos como "Pedro el Morato" o "el Pajarito".

Palabras clave: flamenco, trovo, cante de las minas, cante del trovo, malagueña del trovo, cante de Pedro el Morato, cante del Pajarito.

\section{Abstract}

The world of the "trovo" (sudden popular poetry) of the Sierra Minera de Cartagena-La Unión (Murcia-Spain) is intimately linked to the evolution of the "cantes de las minas" (mining song): it is considered, in fact, one of the nutritional sources of the repertoire of lyrics of the "cante minero" (mining folk singing). In this article some of the best known are brought up, as well as others created by "troveros" (poets who improvise their verses) in their role as poets. Some of the malagueña's melodies used in "veladas troveras" (poetic contests) are also remembered, as well as certain flamenco styles linked to the names of mythical names such as "Pedro el Morato" or "El Pajarito". 


\section{Trovo, poesía y cante}

Junto al baile y al toque, el cante constituye una de las tres vías básicas de expresión del flamenco. Sin embargo, como afirma Félix Grande en su prólogo al poemario de José Cenizo Con pocas palabras (2009), sin la poesía, «el cante, pura y sencillamente, no habría existido nunca» (p. 9)1. De hecho, las letras tienen una importancia clave en este arte, además de su indudable valor humano y documental.

Los principales rasgos de las letras flamencas -y, por ende, de las del cante minero- son la síntesis y la precisión. Vertidas en formas poéticas simples y expresadas con sencillas palabras, hacen gala de una escueta concisión, lo que no es obstáculo para que encierren a menudo ideas o sentimientos profundos. Pero en ellas no hay lugar para lo retórico o lo superfluo; se limitan a hablar de las cosas humanas, y lo hacen con un léxico limitado, en ocasiones vulgar, en el que afloran los usos propios del habla popular.

Son, además, inseparables de la música: nacieron para ser cantadas y sólo así alcanzan su plenitud. De hecho, despojadas de su melos, adolecen a veces de ese mal que Cervantes censuraba en muchas coplillas y estrambotes de su tiempo, cuyos versos -decía- «cantados encantan y escritos suspenden»².

Si bien se conoce o sospecha en algún caso la mano de autores cultos, buena parte de las letras del cante minero son anónimas; o han alcanzado esa anonimia necesaria para que el pueblo las sienta como suyas.

El mundo del trovo, un tipo de poesía popular repentizada muy en boga en tierras almerienses y murcianas, es considerado una de las fuentes nutricias del repertorio minero. Apunta García Cotorruelo (1959) que en la Sierra de Cartagena-La Unión trovo y cante minero siguieron caminos paralelos: ambos

\footnotetext{
1 Pero en su conocida obra Memoria del flamenco dice también esto otro: «si le quitamos la música al flamenco nos quedamos en cueros» (Grande, 1979: 640).
}

2 Cervantes, Don Quijote II, 38. 


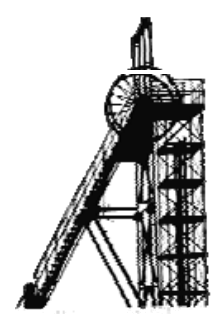

tuvieron su momento cimero en torno a 1900 y también ambos se encontraban en una situación precaria similar poco antes de la puesta en marcha del Festival del Cante de las Minas de La Unión, cuya primera edición se celebró en 1961. Para García Cotorruelo, esa estrecha relación se deriva del hecho de tener ambas expresiones artísticas unos mismos representantes, teniendo tal vez en mente la figura de Antonio Piñana, maestro reconocido del cante minero, que también hizo sus bolos en veladas troveras.

Como señala Casimiro Bonmatí (1988), el acto de trovar no consiste tan sólo en versificar o versear, sino que esto ha de hacerse de forma súbita, improvisada. Afirma también que «a los que practican este arte se les denomina troveros; y sus composiciones, en términos generales, reciben el nombre de trovos ${ }^{3}$ » (p. 39). Pero matiza: «si un trovero, en vez de improvisar, se tomara tiempo para elaborar su verso, retocándolo una y otra vez cuidada y parsimoniosamente, dejaría de ser trovero para quedarse simplemente en poeta» (ibídem). Una observación que ya antes había formulado Asensio Sáez (1965):

Cuando el trovero deja la improvisación y se recoge en los claustros de la preceptiva para elaborar premeditadamente los arabescos de su verso -esto quito o pongo, esto me gusta o no me gusta- el trovero deja de serlo para convertirse lisa y llanamente en un poeta (p. 154).

Es importante esta matización pues, admitiendo que los troveros han contribuido a engrosar el repertorio de letras de los cantes mineros, no todas sus creaciones han de ser consideradas trovo.

Destaca Tomás Loba (2015) que una de las cualidades inherentes al trovo es la oralidad, ya que el trovo se materializa a través de la palabra hablada. En

\footnotetext{
${ }^{3}$ Ángel Roca (1976) ofrece dos definiciones de trovo, la segunda de ellas, más constreñida: «Llámase trovo [...] al arte de improvisar coplas, sin llevarla pensadas ni escritas de antemano, sino ajustándose estas improvisaciones al momento accidental de cara al público. Trovo es también en lo específico glosar una cuarteta» (p. 404). Para Tomás Loba (2015), sin embargo, «trovo es todo lo que implique repentismo poético» (pág. 174). El término "repentismo" no lo recoge la RAE, que sí incluye las voces "repentista" -«persona que improvisa un discurso, poesía, etc.» - y "repentizar" «improvisar con rapidez»-, términos ambos derivados del adjetivo latino repens (súbito, repentino).
} 
realidad, habría que decir cantada, pues de costumbre los versos se dicen cantándolos, la mejor forma de asegurar una correcta impostación de la voz y que ésta se escuche en espacios amplios. Pero, si un trovero no tiene facultades o no sabe hacerlo, tiene que recurrir a un cantaor, al que dicta su improvisación verso a verso para que la cante por él ${ }^{4}$.

Hay que tener también en cuenta, como señala Bonmatí (1988), que una velada trovera transcurre siempre cara al público: ante él los contendientes han de demostrar su «singular facilidad para improvisar poesía» y ser también capaces de «contestar en verso a cualquier pregunta o tema que se les proponga» (p. 39).

La memoria popular, la mano ágil y oportuna de un escribiente y más recientemente las grabaciones en audio o vídeo permiten fijar lo que acontece en una velada trovera: La historia del trovo del cartagenero Ángel Roca (1976) es un testimonio elocuente de esa feliz ocurrencia, como también lo es el librito del trovero José Castillo Algo de mi vida: un viaje a la Corte de España (Castillo, 1923). De no ser así, por su naturaleza efímera, el trovo está condenado a una existencia breve. Hay, sin embargo, otra forma de inmortalizar un trovo y es que el cante lo fije o lo perpetúe. A este respecto, hay una simpática y conocida anécdota.

El mítico trovero José Marín, nacido en el campo de Cartagena en el último cuarto del XIX, recibió una invitación para mostrar su arte en tierras almerienses. Se presentó allí en compañía de otro ilustre repentista, José Castillo, de cuidadas formas e impecable en su forma de vestir: todo lo contrario que Marín, cuya apariencia era más bien rústica. Extrañado el público, empezó a hacer comentarios poniendo en duda la valía del trovero palmesano,

\footnotetext{
${ }^{4}$ Según refleja Castillo en su libro autobiográfico Algo sobre mi vida (1923), éste fue el caso de Marín, que acostumbraba a echar mano de los servicios de Ramón "el Pechinela", «su predilecto cantaor» (p. 31). Por una foto recogida por Ángel Roca (1976) se sabe que otro de los escoltas de Marín fue el cantaor almeriense Bartolo "el de Oria" (p. 101).
} 


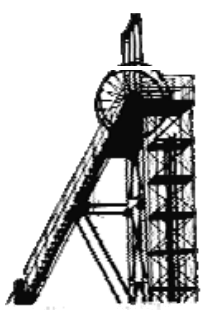

al que juzgaban sólo por su pobre apariencia. Castillo, que captó el ambiente, dio aviso a Marín, que se arrancó con este par de quintillas:

De un obrero que no pudo
recibir otra instrucción
que la del trabajo rudo,
del fondo del corazón,
Pueblo, recibe el saludo.

Soy piedra que a la terrera cualquiera me arroja al verme, soy escombro por fuera, pero en llegando a romperme doy un metal de primera 5 .

La segunda de ellas es una de las letras de solera del cante minero. La grabó por tarantas en 1928 para el sello Gramófono (referencia AE 2039) el sevillano Manuel Escacena ("Escasena”), acompañado a la guitarra por Miguel Borrull. Lo hizo de este modo:

Ay, a la terrera, soy piedra que a la terrera cualquiera me arroja al verme, parezco escombro por fuera pero en llegando a romperme, ay, doy un metal de primera, tengo un metal de primera.

Años antes, en 1923, la había registrado para la casa Pathé (referencia 2242) otro gran tarantero, Joaquín Vargas Soto "el Cojo de Málaga", a quien acompaña a la guitarra Miguel Borrull, que lo hace en tono de tarantas con cejilla al 4 (tono real La\#). La canta así6:

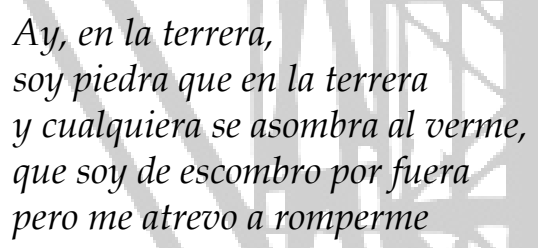

${ }^{5}$ Ángel Roca (1976, p. 46) se hace eco de esta anécdota que, como él mismo señala, relata el propio Castillo en su librito autobiográfico Anecdotario introspectivo, publicado en Cartagena en la década de los 50 del pasado siglo y reeditado años más tarde por Luis Díaz Martínez (Castillo, 1954/ 1994).

6 Puede escucharse en https://youtu.be/SXnZU5oFn30. 
y tengo un metal de primera7.

Más allá del consabido proceso de adaptación lírica, que lleva a repetir uno de los versos de la quintilla a fin de conseguir los seis tercios en los que se articula la melodía de los cantes derivados del fandango (malagueñas, tarantas, mineras, cartageneras, etc.) -habitualmente empleados como vehículo musicalse observa que la letra primera ha variado ligeramente en ambos casos, aclimatándose a la personalidad y los modos expresivos del intérprete. De hecho, éste puede sustituir palabras de la copla original por otras, como puede también forzar la métrica octosílaba interpolando "ayes" y palabras nuevas, o incluso repetir algunas de ellas. Esto es habitual en el flamenco, pero no así en el trovo.

Por otra parte, si bien tanto trovo como flamenco son artes poéticomusicales, en el primero prevalece la palabra sobre la música, cuya principal función es servir de medio transmisor. En cambio, en el flamenco, la expresión musical se cuida sobremanera, prevaleciendo sobre la propia intelección del texto. En el trovo, lo más importante y valorado por el público es el mensaje, que es preciso entender con claridad; en el flamenco, lo es el intérprete y la producción sonora $y$, siendo importante el texto, con frecuencia éste es apenas inteligible, sometido a las expansiones expresivas del melos.

Si no propiamente del trovo, al menos de su órbita se ha nutrido también el cante minero. De hecho, son varios troveros que, cuando han tenido ocasión, han ejercido también como poetas. Es bien conocida esta letra del trovero Ángel Roca, que Manuel Romero interpreta magistralmente por tarantas junto a la guitarra de Antonio Piñana en el disco de 1985 La Unión: cante de las minas (Hispavox (30) 130 346):

Por favor, no llores, madre,

\footnotetext{
7 Puede verse en transcripción musical en los anexos. Un año después, en 1924, el Cojo de Málaga volvió a grabarla, esta vez para el sello (referencia AE 1275) y acompañado a la guitarra por Miguel Borrull. En este registro canta así el último verso: "que tengo un metalico, primo, de primera".
} 
porque quiero ser minero: fue minerico mi padre, que lo heredó de mi abuelo y yo lo llevo en la sangre.

Y suyas son también estas otras grabadas por Manuel Romero y Antonio Piñana por fandangos mineros, que pueden escucharse en ese mismo disco:
Una rubia en Cartagena me ha robado el corazón, ahora que estoy en La Unión me lo ha robao una morena: ya no tengo salvación.
Marinero, marinero, no vuelvas por Cartagena, que, si te dijo "-Te quiero" aquella guapa morena, se casó con un minero.

Otra letra famosa que aparece en él es ésta del unionense Andrés Cegarra Cruz "Conejo" 8 , que Encarnación Fernández popularizó por mineras:

Quiero hacer fuerza y no puedo, siento de la muerte el frío: no me abandones, Dios mío, porque queda otro barreno entre el escombro perdío.

De Basilio Martínez, también unionense y aficionado al trovo y al cante, son las dos siguientes que cantaron por mineras, respectivamente, Pencho Cros y Encarnación Fernández:

Se oye un grito en el rehundio que me hiela el corazón: Dios mío, ten compasión, que un barreno me ha crujío y no tengo salvación?.

\footnotetext{
${ }^{8}$ Así consta en el recopilatorio La carpeta de Pencho Cros (Cros, 1989, p. 185). Sin embargo, en los créditos del disco se atribuye por error al trovero de Puente Tocinos (Murcia) José Travel "el Repuntín". Se incluye en el álbum Cumbre flamenca en La Unión. Hispavox 2567946044 (1990).

9 Puede escucharse a Pencho Cros interpretar esta minera en el disco Festival Nacional del Cante de las Minas (Antología). RTVE 62064 (2000).
} 

La mejor copla minera que en la sierra se ha cantao la cantó Juanico Vera cuando estaba de encargao en la mina La Palmera10.

Tanto en el trovo como en la poesía flamenco-minera se dan fenómenos como la previsibilidad en la rima: "corazón-La Unión"; "taranta-garganta"; "Cartagena-pena", etc. Y afloran también las recurrencias versales, esto es, versos íntegros, octosílabos perfectos que aparecen y reaparecen en muchas coplas: "el Rojo el Alpargatero", "Conchita la Peñaranda", "en el fondo de una mina", "trabajando en una mina", "de Cartagena a Herrerías", etc.. Se trata de recursos harto frecuentes en la poesía popular repentizada o escrita a vuela pluma que explican, por otra parte, el estrecho paralelismo que se observa entre algunas letras. Un ejemplo lo tenemos en la siguiente quintilla, que el cantaor cartagenero Manuel González "Guerrita” grabó en 1930 por tarantas, junto a la guitarra de Miguel Borrull (Odeón 182.870):

De La Unión a Cartagena oí a un tartanero cantar: lleva su vía en el cante y hasta el alma se le alegra cuando canta por Levante.

Cuatro años más tarde, también por tarantas, el Niño de Marchena grabó acompañado por el guitarrista Paco Hortelano esta otra letra cuyo primer verso es idéntico al de la anterior (Gramófono GY 152):

De La Unión a Cartagena te conocí una mañana: como te vi tan bonita yo te llevé en mi tartana a oír misa en la ermita.

10 Encarnación Fernández, "La mejor copla minera". El cante hondo de Encarnación Fernández. Movieplay 01.2105/0 (1981). 
La calle de Canales es un lugar emblemático de la ciudad portuaria, considerado por algunos cuna del cante cartagenero, pues Antonio Grau Mora “el Rojo el Alpargatero" regentó en ella un local que devino meca para los cantaores de la zona. Se menciona en muchas coplas; por ejemplo, en estas dos que recoge el cancionero de Martínez Tornel (1892):

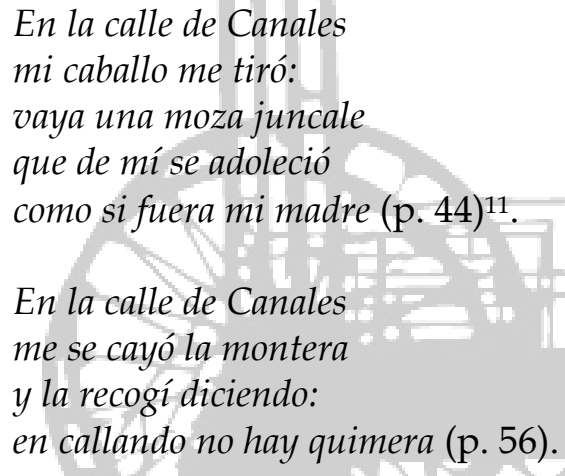

Los lectores de El Diario de Murcia -publicación que dirigía el escritor y periodista murciano- le remitieron esta otra (Martínez Tornel, 1892b), en la que asoman algunos nombres míticos del cante minero:

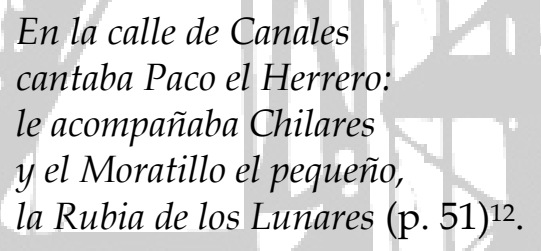

Federico Casal (1948), cronista oficial de Cartagena, recoge esta variante en su ensayo sobre el folklore de la ciudad departamental, que suma los de otros artistas famosos de la época, entre ellos, el ya mencionado “Rojo el Alpargatero":

$$
\begin{aligned}
& \text { En la calle de Canales } \\
& \text { cantaba Paco el Herrero, } \\
& \text { le acompañaba el Chilares, } \\
& \text { el Rojo el Alpargatero }
\end{aligned}
$$

\footnotetext{
${ }^{11}$ Andrés Barceló (s/f, p. 43), recoge esta variante: "En la calle de Canales/ un caballo me tiró,/ y las muchachas decían:/ -¡Qué lástima y que dolor/ tan flamenco que venía!".

${ }^{12}$ No sabemos de qué artista puede tratarse, pero en 1863 Sebastián Iradier, el famoso compositor de "La paloma", publicó otra habanera que lleva por título "La Rubia de los lunares".
} 
y Enrique el de los Vidales (p. 49).

Antonio Piñana la grabó por cartageneras en 1968 en un registro discográfico para la casa Belter (52.179). Como se acostumbra en esta modalidad de cante, el maestro Piñana desarrolla el primer tercio quebrando el segundo verso, del que sólo emplea la segunda mitad. Alarga, además, el segundo con la interpolación de nuevas palabras, algo que también sucede en el tercio siguiente:

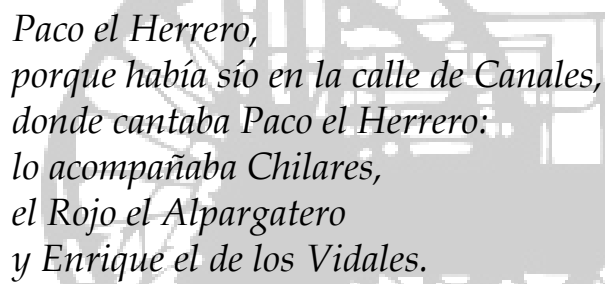

En su Cancionero popular de Cartagena, Puig Campillo (1953) recoge esta otra copla de rancio abolengo:

$$
\begin{aligned}
& \text { En la calle de Canales } \\
& \text { fue donde perdí el sombrero } \\
& \text { y se lo vino a encontrar } \\
& \text { El Rojo el Alpargatero } \\
& \text { y no me lo quiso dar (p. 181). }
\end{aligned}
$$

El prolífico cantaor Antonio Pozo "el Mochuelo" la grabó en 1912 para el sello Odeón (referencia 41118), sirviéndose de una las variantes de la melodía que hoy identificamos como "malagueña" o "taranta de Fernando el de Triana" (Ortega, Soler, García y Gómez, 2019, pp. 547 y ss.) ${ }^{13}$. Manuel López, que es el guitarrista que lo acompaña, impone un tenue ritmo ternario de aire abandolao ${ }^{14}$. Como suele ser habitual en algunas modalidades de cante por malagueñas,

${ }^{13}$ Como primer cuerpo canta con la misma melodía esta otra conocida letra: "Virgen del Carmen,/ que dime tú dónde estaba la Virgen del Carmen,/ tan hermosa y peregrina,/ que porque a mí me han convidao esta tarde/ pa que sea la madrina/ que y en el bautismo de un ángel". Al comienzo de la grabación se escucha una voz que anuncia el cante: "Taranta, cante murciano, cantado por el Mochuelo. Disco Odeón".

${ }^{14}$ Fórmula rítmica de acompañamiento cuyo diseño recuerda al característico del bolero español: 


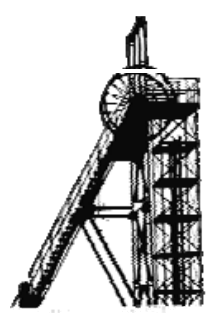

cartageneras y tarantas, el Mochuelo quiebra el segundo verso para construir el primer tercio, aunque no es el único de los versos alterado por algún cambio:

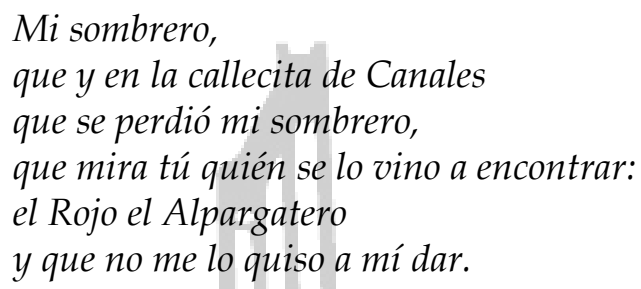

Décadas después, Pepe Marchena recordaría esta misma letra en el segundo volumen de sus Memorias antológicas del cante flamenco, que grabó en 1963 junto a Paquito Simón para la casa Belter (referencia 12.718). Rotulada como cartagenera, Marchena echa mano de una melodía con ribetes de fandango, que Simón acuna a la guitarra con un cadencioso aire binario de taranto ${ }^{15}$.

Blas Vega (1973), Navarro (1989/2014) y Gelardo (2008) atribuyen la copla que acabamos de mencionar letra al cantaor sevillano Manuel Escacena que, al parecer, compartió pensión en Madrid con Antonio Grau Dauset, hijo del Rojo el Alpargatero. Cuentan que cuando el vástago del Rojo se la cantó a su padre, éste le respondió con esta otra copla (Gelardo, 2008):

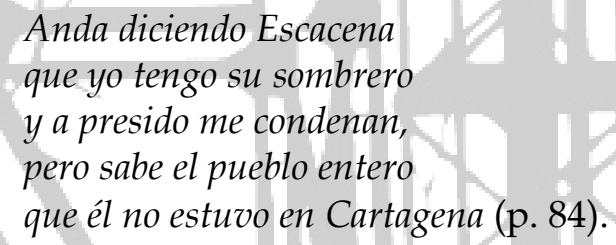

José Salazar Molina "Porrina de Badajoz" grabó en 1972 para el sello Belter (referencia 22.623) una variante de la primera letra, que contextualiza en la región jienense; dice así:

Se me había perdío el sombrero ay, que por las calles de Linares se había perdío mi sombrero

\footnotetext{
${ }^{15}$ Marchena canta así esta copla: "Se me perdió mi sombrero,/ en la calle de Canales/ se me ha perdío el sombrero,/ quién se lo vino a encontrar,/ el Rojo el Alpargatero/ y no me lo quiso dar".
} 


\author{
y quién se lo vino a encontrar \\ y el Rojo el Espargatero \\ ay, que por las calles de Linares, que mare, mare, que mare, \\ mare, mare de mi alma.
}

Porrina presenta el cante como «taranta clásica de Linares de Diego Cabeza ${ }^{16}$ ». Su hijo, Juan Salazar "Porrina hijo", que lo acompaña a la guitarra, marca un claro aire de taranto y como tal se identifica este cante en la carátula del disco.

\title{
2. La música del trovo
}

En las veladas troveras típicas de la Sierra Minera de Cartagena-La Unión se emplean dos estilos de cante en función de la estrofa poética: uno con aires de guajira, cuando la controversia transcurre por décimas; y otro con aires de malagueña, si lo hace por quintillas. Más recientemente, es posible también escuchar las quintillas del trovo cantadas por aires de fandango onubense. Y si los troveros no tienen la solvencia vocal exigida o a falta de cantaores, se estila asimismo la modalidad de trovo hablado o recitado, en ocasiones con una guitarra de fondo que deja oír los conocidos sones del toque por tarantas ${ }^{17}$.

Centrándonos en la malagueña, los troveros y los cantaores que los escoltan recurren casi siempre a una misma melodía, con la que se identifican y dominan, y que les sirve de vehículo musical para lanzar al público sus versos repentizados. El poder evocador de su ritmo, aun siendo éste libre por no ceñirse a un metro concreto, resulta seguramente útil como estímulo a la repentización.

Troveros como José Travel "el Repuntín", Manuel Cárceles "el Patiñero" o Ángel Cegarra Olmos "Conejo II", tenían su propia melodía de malagueña del trovo. Y otro tanto puede decirse del cantaor Alfonso Conesa Meroño "el Levantino", acompañante, entre otros, del trovero José Martínez Sánchez "el Taxista".

\footnotetext{
16 También conocido por el apodo de Diego "el Vagonero"; cf. Chaves y Kliman 2012, p. 351.

17 En las veladas tradicionales también se recurría a esta modalidad de trovo en los momentos álgidos de la pugna para dar mayor agilidad al espectáculo.
} 


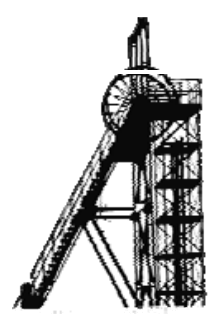

Precisamente, de sendas controversias mantenidas mediada la década de los 80 del pasado siglo por estos conocidos representantes del repentismo murciano recogemos en transcripción en los anexos las melodías de sus malagueñas troveras ${ }^{18}$. En la primera de ellas, "el Repuntín" y "el Taxista" -a quien auxilia como cantaor "el Levantino" - debaten en verso sobre la OTAN, tema estrella del momento, que dio pie incluso a un referéndum nacional ${ }^{19}$. La segunda está protagonizada por "el Patiñero" y "Conejo II", tradicionalmente rivales, que discuten sobre la mujer ${ }^{20}$.

Desde una perspectiva general, las malagueñas de todos ellos, a pesar los matices que las diferencia, guardan una cierta similitud. Por lo pronto, se ajustan a un mismo patrón armónico, por el que vela la guitarra de Salvador Martínez “el Fontanero". Similar es también el planteamiento de sus tercios ${ }^{21}$, cuya primera mitad suele transcurrir en estilo silábico -para facilitar la correcta intelección del verso-, cerrándose con un melisma de cierta extensión y dificultad. Además, la melodía describe siempre un diseño descendente, pues avanza desde el registro agudo al grave. La única excepción la constituye la malagueña acuñada por Ángel Cegarra "Conejo II", que transcurre de preferencia en los tonos medios de la escala y en cuyos tercios -especialmente el segundo y el sexto- asoma la típica sonoridad de los cantes mineros y el fandango lucentino, caracterizada por el uso del quinto grado rebajado. Hay, además, un detalle que creemos oportuno señalar, y es que "el Fontanero", que acompaña en tono de malagueñas, afina la guitarra un tono más bajo de lo habitual, democratizándolo así y facilitando la intervención de los troveros en litigio.

18 Ambas grabaciones nos llegaron por gentileza de Ángel Cegarra Cruz y gracias a la mediación de nuestro buen amigo y paisano José Cros Zaplana "Pepe Cros".

19 Puede escucharse en https://youtu.be/bGuurL_jVxw.

20 Puede escucharse en https://youtu.be/RODSRZVuFtQ.

${ }^{21}$ Así se denominan cada uno de los fragmentos melódicos -seis en total- en los que se articula la melodía de una malagueña. 
Pero esto que acabamos de describir pertenece, por desgracia, a una época pasada. En la actualidad, el aspecto musical del trovo de la Sierra Minera se ha descuidado bastante. $\mathrm{Y}$ es de lamentar pues los versos adquirirían seguro otra entidad revestidos del melos, ganando también enteros el espectáculo. Pero tampoco, salvo raras excepciones, cantaores de solvencia se prestan, como antaño, a participar en las veladas troveras.

\subsection{Antonio Piñana, cante del trovo}

No fue el caso de Antonio Piñana, que lo hizo con frecuencia y que registró, además, en disco un hermoso y paradigmático ejemplo de cante del trovo, incluido en su álbum de 1970 El cante de las minas (Hispavox-HHS 10371). Como es habitual, lo acompaña su hijo, Antonio Piñana Calderón, que lo hace por malagueñas y con la/guitarra afinada ligeramente por encima del diapasón. Esta es la copla 22 :

\section{Los de San Antonio Abad fueron a Quitapellejos a un baile de sociedad, por llevar el traje viejo no les dejaron entrar.}

Se mencionan en ella dos barrios tradicionales de Cartagena: el de San Antón y el de La Concepción, también conocido como Quitapellejos, ya que allí se desollaba a los animales para convertir sus pieles en cuero, utilizándose también su rambla como vertedero para los restos (Murcia y Ortega, 2016).

Décadas antes, en 1929, Francisco Montoya Egea "el Niño de la Huerta" grabó ya este letra en un registro para el sello Odeón (referencia 182.661). Lo acompaña el guitarrista Manolo de Badajoz, que lo hace en tono de tarantas con cejilla al 3 (tono real La). Se trata de una hermosa taranta, cuya melodía conduce con total maestría y fluidez el Niño de la Huerta. Destacamos de ella la salida, de considerables dimensiones, así como el planteamiento del cuarto

22 Puede escucharse en https://youtu.be/4sKtgtW2crM. 


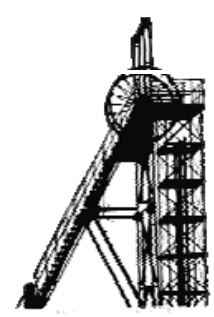

tercio, que evoca al de la minera actual. Se recoge en el volumen 38 de la colección La época dorada del flamenco editada por el sello DIENC (CD 194, 2005), aunque allí se presenta como "cartagenera" y curiosa y erróneamente lo titulan "Que fueron a quitar pellejos"23. En los anexos puede verse en transcripción musical ${ }^{24}$.

Martín Salazar (1998) sugiere incluir el cante del trovo grabado por Piñana dentro del grupo de las que él denomina "malagueñas viejas", pero desconocemos basándose en qué. En cualquier caso, el cante tiene, en efecto, factura malagueñera y de ahí que sea también conocido como malagueña del trovo. Su hijo, Antonio Piñana, acompaña por arriba y, si bien, al inicio del preludio rememora el típico compás ternario que arropa los cantes abandolaos, a la conclusión del mismo renuncia al corsé del metro decantándose por un ritmo libre, en consonancia con el devenir de los tercios del cante. Este cante del trovo grabado por Antonio Piñana -cuya transcripción musical puede verse en los anexos- constituye un bonito e interesante ejemplo de malagueña, de ejecución nada fácil y, por eso, efectista y atractiva para el oyente.

\section{La huella de los troveros en el cante}

Por algunas de las coplas citadas en este trabajo han asomado los nombres de artistas legendarios, supuestos forjadores del cante minero: el Rojo el Alpargatero, Enrique el de los Vidales o Paco el Herrero; a ellos podrían sumarse los del Ciego de la Playa, el Marmolista, Juan el Albañil, Perico Sopas, el Pajarito o Pedro el Morato. Salvo el caso de Antonio Grau "Rojo el Alpargatero" -mítico creador e intérprete a quien ya Núñez de Prado dedicara un jugoso capítulo en sus Cantaores andaluces (1904) y, más recientemente, Pepe

${ }^{23}$ En el catálogo de Odeón se rotula, en cambio, como taranta y lleva por título "En un baile de Sociedad".

24 Puede escucharse en https://youtu.be/eTHogODIutY. 
Gelardo (2007), un muy documentado estudio-, muy poco se sabe de ellos, más allá de anécdotas o alusiones de pasada.

\subsection{Cantes de Pedro el Morato}

Otra excepción es, tal vez, Pedro el Morato. Hasta no hace mucho identificado como Pedro Segura y tenido por natural del pueblo almeriense de Antas (Grima y Torres, 1995), recientes investigaciones parecen apuntar a que era oriundo de Vera -como pregonan algunas coplas populares- e hijo expósito adoptado por el matrimonio compuesto por Antonio María Alonso Albarracín y Ana María Morata, de donde le vendría el apodo 25.

La figura del Morato ha quedado inmortalizada en numerosas letrillas, algunas de rancia tradición, otras fruto del oportunismo del momento, en cualquiera de los casos reflejo de su fama.

Muy conocida es ésta que apunta uno de los oficios del personaje:

$$
\begin{aligned}
& \text { Soy del Reino de Almería } \\
& \text { donde nacen los tempranos } \\
& \text { y al amanecer el día } \\
& \text { me encuentro a Pedro el Morato } \\
& \text { vendiendo verdulería. }
\end{aligned}
$$

La grabó en 1913 para el sello Gramophone (referencia 262.166) Antonio Chacón, acompañado a la guitarra por Ramón Montoya ${ }^{26}$. Identificado en la etiqueta del disco como "mineras n. ${ }^{\circ}$ ", se trata de un cante con hechuras de taranta, caracterizado por un sencilla y atrayente melodía que el cantaor jerezano interpreta con un gusto y dominio de la voz exquisitos.

Pasado el tiempo, Enrique Morente lo recrearía en su álbum de 1969 Cantes antiguos del flamenco (Hispavox HHS 10-355, 1969), que grabó junto al

${ }^{25}$ Cf. Jennifer Simón Carrión. El "redescubrimiento" de Pedro el Morato (Ideal: Levante, 29 de abril de 2012). Recuperado de https://levante.ideal.es/actualidad/noticias/201204/29/el-redescubrimientode-pedro-el-morato.html?ref=https://www.google.com/.

26 Para el estudio de la discografía de Chacón véase Martín, Soler, Castro y Gamboa (2016). 
Niño Ricardo ${ }^{27}$. Lo presentó entonces como "tarantas de Almería" aunque, años después, volvió a grabarlo para su trabajo discográfico de 1977 Homenaje a D. Antonio Chacón (Clave-Hispavox 18-1380 S), devolviéndole su etiqueta original de "mineras". Lo acompañó entonces a la guitarra Pepe Habichuela, que lo hace con un gusto exquisito, escogiendo el tono de granadina (con cejilla al 1: tono real Do). Precisamente es este el registro que presentamos en los anexos en transcripción musical.

En una obra reciente sobre los estilos mineros se presenta el cante legado por Chacón como "minera de Pedro el Morato" (Chaves y Kliman, 2012). La atribución, aunque bienintencionada, se nos antoja caprichosa pues, más allá de la mención a este personaje en los versos de la copla -aunque choca un tanto que se citara a sí mismo en tercera persona-, es imposible asegurar que la melodía sea fruto del trovero almeriense.

Antonio Piñana, que interpretó también la letra transmitida por Chacón en su EP de 1964 Antonio Piñana: Porque vengo de Almería (La Voz de su Amo, 7EPL 14.092), grabó otra copla que tiene de nuevo como protagonista al trovero almeriense ${ }^{28}$ :

$$
\begin{aligned}
& \text { Soy el mejor de los troveros, } \\
& \text { me llaman Pedro el Morato: } \\
& \text { bien lo sabe el mundo entero } \\
& \text { que de trovo tengo un rato } \\
& \text { y también de verdulero. }
\end{aligned}
$$

Según/los registros de la SGAE, los autores de la misma son el investigador y flamencólogo José Blas Vega y el guitarrista Félix García Vizcaíno "Félix de Utrera", que solían firmar al alimón sus creaciones bajo el seudónimo de "Ópalo y Vizcaíno". Identificada como "cante de El Morato", la grabación se incluye en el LP de 1971 Todo el cante de Levante, todo el cante de las

\footnotetext{
27 Puede escucharse https://youtu.be/-1_eXidQp2s.

${ }^{28}$ Puede escucharse en https://youtu.be/SwkTPePvtoY.
} 
minas (Clave-Hispavox, 18-1234 S). Su línea melódica guarda un estrecho parecido con la de la minera clásica, como delata el planteamiento y desarrollo de alguno de sus tercios. Antonio Piñana hijo, que lo acompaña como siempre a la guitarra, lo hace en tono de tarantas con cejilla al 1 (tono real Sol).

José Núñez Meléndez “Pepe de la Matrona” grabó un cante con esta otra letra de índole autobiográfica, en la que el Morato presenta sus credenciales ${ }^{29}$ :

\section{Me llaman Pedro el Morato y soy natural de Vera; con mi guitarra en la mano, vaya tela y venga tela, vaya tela de verano.}

Incluido en el doble LP de 1973 que lleva por título Pepe de la Matrona. Tesoros del flamenco antiguo (Hispavox - HH 10-346/47), el estilo se identifica como "taranta de Pedro El Morato". Lo acompaña a la guitarra Manolo el Sevillano, que lo hace por tarantas con cejilla al 3 (tono real LA), aunque afinadas las cuerdas un poco más bajo de lo habitual.

La letra, de origen popular, parece surgir del cruce de estas otras dos recogidas en el cancionero de Martínez Tornel (1892a):

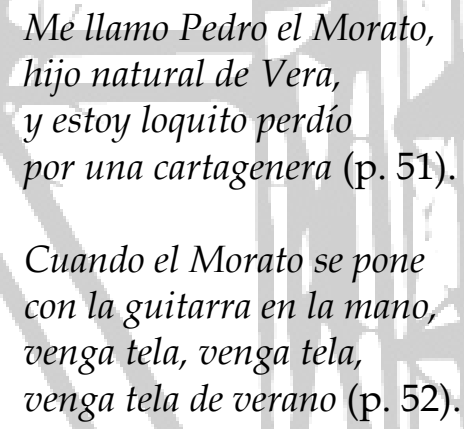

Manrique y Alba Villagrán (1979) catalogan el cante registrado por el de la Matrona como un estilo de taranta antigua de singular sobriedad, cuya melodía -que puede verse en transcripción musical en los anexos- recuerda a la de las mineras grabadas por Chacón y a la del taranto.

29 Puede escucharse en https://youtu.be/NIKIjpmdlGk. 
Reminiscencias de lo que actualmente identificamos como taranto tiene también la melodía de un cante interpretado por Pastora Pavón, en cuya letra asoma una vez más la figura de Pedro el Morato ${ }^{30}$ :

Fui la otra noche al teatro y hablé con la Emperatriz, con ella conversé un rato: -No hay general como Prim, para trovar, el Morato ${ }^{31}$.

La grabación -cuya transcripción musical puede verse en los anexos- la realizó en 1912 para el sello Gramophone (referencia 3-63053) y se escucha como segundo cuerpo tras la cartagenera (o taranta de Chacón) "A la derecha te inclinas" 32 . Ramón Montoya, que la acompaña a la guitarra, lo hace en tono de granadinas.

En julio de 1913, de nuevo Pastora grabó en Berlín esta otra letra para la casa Homokord (referencia 70657) $)^{33}$ :

Para, para, carretero,

llévame, por caridad,

a las minas del Romero,

porque acaban de asesinar

al hermano que más quiero.

La acompaña a la guitarra Luis Molina, que lo hace en tono de tarantas con cejilla al 4 (tono real La\#).

El cante, identificado en la etiqueta del disco como «Tarantas: El carretero», tiene, efectivamente, factura de taranta. Su melodía es muy similar a

\footnotetext{
${ }^{30}$ Puede escucharse en https://youtu.be/PpX6SCckAuQ (segundo cuerpo).

${ }^{31}$ Martínez Tornel (1892a, p. 47) recoge esta variante de la letra: "Anteanoche fui al teatro/ y vide a la Emperatriz,/ platiqué con ella un rato/ y me dijo la infeliz:/ -Ya murió Pedro el Morato".

${ }^{32}$ La Consejería de Cultura de la Junta de Andalucía impulsó la recopilación integral de la obra discográfica de Pastora Pavón, que publicó en 2004 bajo el título La Niña de los Peines, patrimonio de Andalucía (Sevilla: Fonotrón). En este magnífico trabajo, que contó con la colaboración de renombrados investigadores del flamenco, se recoge un amplísimo y detallado estudio de sus registros sonoros.
}

33 Puede escucharse en https://youtu.be/iLfpeDkYvNo. 
la de otra taranta -si bien rotulada como «malagueñas n. ${ }^{\circ} 3$ »- que la cantaora sevillana grabó en 1912 para el sello Gramophone (referencia 3-63063) con esta copla:

\section{Entre las cenizas muertas se mantiene el fuego vivo; entre el amor y los celos anda el demonio metío 34 .}

Esta misma letra la había grabado en 1908 para la casa Zonophone (referencia X 5-52013) un paisano suyo, el cantaor Manuel Escacena “Escasena”, acompañado por Román García a la guitarra. Pero, a diferencia de la de Pastora, su melodía va en la línea de la conocida como "taranta de la Gabriela" (Ortega, 2017, p. 112).

Eugenio Noel atribuye dicha copla a José María Celdrán “el Nene de las Balsas", un polifacético artista murciano capaz tanto de interpretar una pieza del género lírico como de adentrarse por la senda del flamenco. A pesar de su fama de polémico antiflamenquista, Noel atesoraba erudición flamenca como se desprende de este párrafo extraído de su novela Martín el de la Paula en Alcalá de los Panaderos:

Hay que ver cómo Centeno canta medias granadinas, el fandango del Alosno: Como a ti te lo pusieron...; el fandango de Juan María, el fandanguillo de Almonte, las tarantas de Vallejo, la saeta de la Alfalfa... Las soleares de Paquirri nadie como Diego Bermúdez, el Viejo, y las seguiriyas de Silverio, y Los cabales... Y duro a recordar las coplas famosas: el Daba en el reloj la una, de Chacón; el Rosa, si no te cogí, de Loriguillo el de Coín; el cante típico de Silverio: Yo crié en mi rebaño una cordera; el Ay, que entre la ceniza muerta, del Niño de las Balsas (Noel, 1926/2007, pp. 17-18).

\footnotetext{
34 Este mismo patrón melódico lo utilizará la Niña de los Peines en otras de sus grabaciones. Por ejemplo, en esta taranta también grabada en 1913 junto a Luis Molina para Homokord (referencia 70679): “Una mañana de niebla/ un pañuelo me encontré:/ como lo vi de luto/me dio miedo y lo dejé/porque mi hermano era difunto". Y en esta otra grabada ese mismo año junto al mismo guitarrista también para Homokord (referencia 70680): "El Señor murió en el árbol,/ en el árbol de la cruz,/ yo vivo en la calle El Árbol/ tan solo porque vives tú/y pa ti que yo sea algo".
} 


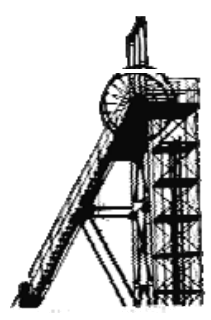

Chaves y Kliman (2012) se apoyan en el testimonio de Noel para sugerir que las tarantas grabadas por la Niña de los Peines que acabamos de mencionar habría que atribuirlas al Nene de las Balsas. En realidad, Noel sólo habla de «coplas famosas» sin identificarlas con estilo flamenco alguno; aunque también es cierto que, al ser representativas de alguno de ellos, la relación se adivina al fondo: malagueña ("Daba en el reloj la una”), media granadina ("Rosa, si no te cogí"), serrana ("Yo crié en mi rebaño una cordera") y taranta ("Ay, que entre la ceniza muerta"). En cualquier caso, el hecho de que Escacena y Pastora interpreten la misma letra pero con distinta melodía parece sugerir que sería aquella y no ésta lo que creó el Nene de las Balsas.

Enrique Morente grabó 1967 para el sello Hispavox (HH 10-324) un cante con esta variante de la letra "El carretero" 35 :

\section{Carretero, carretero, llévame por caridad a las minas del Romero que acaban de asesinar al hermano que más quiero.}

Lo acompaña a la guitarra el guitarrista Félix de Utrera, que lo hace en tono de tarantas con cejilla al 4 (tono real La\#).

Bajo el título "A las minas del Romero" e identificado en los créditos como "cantes de Pedro el Morato", Morente recrea en él un cante grabado en torno a 1911 por un jovencísimo José Núñez Meléndez, conocido por aquel entonces como "Niño de la/Matrona". Hay dudas sobre quién pudo ser el guitarrista acompañante, aunque se sospecha que pudiera ser un tal "Paquito de Granada", que lo hace en tono de malagueñas con cejilla al 6 (tono real La\#).

En la versión del de la Matrona, que grabó para el sello Odeón (referencia A 135.271$)^{36}$, la letra varía ligeramente en el cuarto verso (quinto tercio en su adaptación lírica) ${ }^{37}$ :

\footnotetext{
35 Puede escucharse en https://youtu.be/0ji1Z28iZtM.
} 
Carretero, carretero,

llévame por caridad

a las minas del Romero

porque acaban de matar

al hermano que más quiero.

Le imprime, además, un ligero aire abandolao, que contrasta con el tempo más reposado que le da Morente. Chaves y Kliman (2012, p. 448) afirman que se trata de «una vieja rondeña emparentada musicalmente con los fandangos de Alosno». Como ya advirtió el compositor malagueño Eduardo Ocón en el último cuarto del siglo XIX, «bajo la denominación de Fandango están comprendidas la Malagueña, la Rondeña, las Granadinas y las Murcianas, no diferenciándose entre sí más que en el tono y alguna variante en los acordes» (Ocón, 1874: 81). Desde esta perspectiva y a fin de no complicar en exceso las cosas, nosotros preferimos hablar simplemente de "fandango de cierre".

El de la Matrona concluye los tercios primero y tercero sobre el I grado, mientras que Morente se decanta por una cadencia más habitual en los cantes mineros, finalizándolos con el II grado. El cuarto, sin embargo, lo cierra con el VII grado por debajo del $\mathrm{I}^{38}$, la misma y sorprendente nota que se escucha en la grabación de Pepe el/de la Matrona (Ortega, 2017, p. 293). En los anexos recogemos en transcripción musical las versiones de ambos cantaores.

\subsection{Cantes del Pajarito}

En su/LP de 1970 El cante de las minas, editado por el sello Hispavox (referencia HHS 10-371), Antonio Piñana interpreta una variante de la letra

${ }^{36}$ El cante se escucha en el segundo cuerpo, utilizándolo el de la Matrona como remate a la taranta que canta en primer lugar, "Había publicaito un bando", que Chaves y Kliman (2012) persistentes en su idea de relacionar cada uno de los estilos mineros que abordan en su estudio con un creador- atribuyen al cantaor almeriense "el Marmolista".

${ }^{37}$ Puede escucharse en https://youtu.be/oipq8bvcFeQ (segundo cuerpo).

38 Una cadencia similar encontramos en el mismo tercio de la taranta del Cojo de Málaga "Soy piedra que a la terrera", comentada anteriormente. 


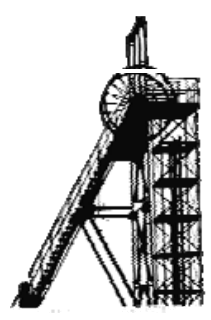

antes mencionada que grabó la Niña de los Peines valiéndose del supuesto patrón melódico de la "taranta del Nene de las Balsas". Piñana la canta así:

\author{
Anoche fui al teatro \\ y vide a la Emperatriz, \\ platiqué con ella un rato \\ y se le ocurrió el decir: \\ - Pa cantar, Pedro el Morato.
}

En la carátula del disco el estilo se identifica como «cantes del Pajarito a Pedro el Morato», .

En su LP de 1972 Antonio Piñana vol. 9 (Triumph-Polydor 2496 210) graba en una misma pista las letras "Fú como el gato" y "Pajarito y el Morato" (aunque en la carátula del disco se presentan en orden inverso), estilos identificados respectivamente como «cantes del Pajarito» y «cantos del Pajarito». Las coplas, firmadas ambas por José Blas Vega (“Ópalo”), son estas:

Con Perico el Morato, con el Ciego de la Playa tendrás que cantar un rato: si no pue ser, que te vayas haciendo "fú" como el gato.

Pajarito y el Morato fueron buenos cantaores, también trovaban un rato pero su vida, señores, fue la tartana y el trato.

En un trabajo discográfico anterior, el LP Antonio Piñana: Todo el cante de Levante, todo el cante de las minas -editado en 1971 por el sello Clave-Hispavox (referencia 18-234-S) -, canta la letra "Soy tartanero de fama", también firmada por José Blas Vega e identificada en la trasera del disco como «cante de El Pajarito»» ${ }^{39}$ :

Soy tartanero de fama

y pongo al cante alegría,

el Pajarito a mí me llaman:

\footnotetext{
${ }^{39}$ Puede escucharse en https://youtu.be/26LMVuESyM0.
} 
no hay en toas las Herrerías

quien tenga mejor tartana.

Lo acompaña como siempre a la guitarra su hijo Antonio Piñana, que lo hace en tono de tarantas con cejilla al 1 (tono real Sol).

Ruipérez Vera (2005), biógrafo y estudioso de la discografía de Piñana, considera esta última grabación como el patrón que define el estilo ${ }^{40}$. Su melodía guarda claras similitudes con la de la actual minera, aunque en el cuarto tercio no se escucha el vertiginoso ascenso melódico característico de ese estilo, como puede comprobarse en la transcripción musical que incluimos en los anexos.

Poco se sabe del Pajarito, cuyo nombre podría ser Antonio Muñoz, según se desprende de un anuncio aparecido en un diario político logroñés a finales de 1892. Comparte escenario con Sebastián Muñoz "Gayarre” (¿pariente suyo?), artista que es posible sea el afamado "Gayarrito" a quien se atribuye la creación de un estilo de malagueña (Ortega, Soler, Ruiz y Gómez, 2019, pp. 275 y ss. ):

CAFÉ DEL SIGLO.- Esta noche a las ocho tendrá lugar en este acreditado y concurrido establecimiento una sesión de cante y baile flamenco por los cantaores Sebastián Muñoz (a) Gayarre y Antonio Muñoz (a) Pajarito y tocaor Manuel Alonso, discípulo del “Niño de Lucena" (La Rioja, 4 de noviembre de 1892).

El cantaor sevillano Antonio Tovar Ríos “Niño de la Calzá grabó en 1945 para el sello Columbia (referencia V 9370) una taranta con esta copla ${ }^{41}$ :

Soy como el ave marina que vuela sobre la mar:

\begin{abstract}
40 Antonio Piñana grabó en 1968 para el sello Belter (referencia 52.179) esta otra letra: "Son las tres de la mañana,/ abre, que soy el moreno,/ y dame por la ventana/ una copa de anís bueno/ que vengo con mi serrana". La melodía, identificada como «minera» en la carátula del disco, es similar a la del estilo que estamos comentando. Pepe Marchena interpreta esta misma letra en el segundo volumen de sus Memorias antológicas del cante flamenco, grabadas en 1963 para el sello Belter (referencia 12.718). El estilo, identificado como «murciana», se nutre de la atmósfera sonora de los cantes mineros con un reposado aire de taranto.
\end{abstract}

${ }^{41}$ Puede escucharse en https://youtu.be/1PPoR8ooxec. 
voy errante en mi destino por no poderte encontrar otra vez de nuevo en mi camino.

Según confirman los registros de la SGAE, la letra es de Ricardo Lapeira Hormaeche ${ }^{42}$, personaje relacionado con el mundo taurino y también representante de artistas, del que sabemos falleció en 1972. En los créditos del disco, el cante se identifica como "taranta del puerto", en consonancia con la temática de la letra. El Niño Ricardo, que lo acompaña a la guitarra, lo hace en tono tarantas con cejilla al 6 (tono real Do).

Chaves y Kliman (2012, p. 163) catalogan este cante como “minera del Pajarito", supuesto discutible, máxime cuando pretenden relacionarlo con el «cante de El Pajarito» grabado por Piñana con el que, más allá de compartir la sonoridad y algún giro típico de los cantes mineros, poco o nada tiene que ver³. En los anexos puede verse también en transcripción musical.

\section{Coda}

El cante flamenco nace de la feliz conjunción de poesía y melos: las coplas nacen para ser cantadas y sólo así alcanzan su cénit.

Síntesis, sencillez y austeridad estilística son los rasgos característicos de la poesía flamenca. También la anonimia pues, aunque toda letra tiene su creador, su nombre en muchos casos ha caído en el olvido con el paso de los años, deviniendo copla popular.

\footnotetext{
42 Junto a Francisco Jiménez, Lapeira es también autor de algunos fandangos interpretados por la Niña de la Puebla, que pueden escucharse en https://www.youtube.com/watch?v=9FfdBoeGbwI. Lapeira es también el creador de esta letra de taranta que, en compañía del Niño Ricardo, Juanito Maravillas grabó en 1950 para la casa Columbia (referencia R-14920): “Un día contemplaba el agua/ que corría por la ribera/ y en su agua cristalina,/como si fuera una perla,/ yo vi tu cara divina".

${ }^{43}$ Puestos a elucubrar, Chaves y Kliman sugieren que las divergencias que se aprecian entre las diferentes versiones registradas por Piñana del "cante del Pajarito" y la grabación del Niño de la Calzá podrían deberse a que beben de fuentes diferentes: Piñana, de Antonio Grau Dauset, el hijo del Rojo el Alpargatero; el Niño de la Calzá, de Canalejas de Puerto Real, con quien participó en diferentes festivales promovidos por el Frente Popular en torno a 1937.
} 
El trovo -manifestación que aúna poesía y música- es considerado una de las fuentes nutricias del repertorio minero. Pero también los troveros, en su rol como poetas, han contribuido a su engrosamiento.

La malagueña, junto a la guajira, es uno de los vehículos musicales para la repentización poética en la Sierra Minera de Cartagena-La Unión. Por lo general, cada trovero -o el cantaor que lo asistía- echaba mano de su propia melodía de malagueña a la hora de improvisar los versos. A este respecto, el cantaor cartagenero Antonio Piñana ha dejado grabado un singular y llamativo ejemplo de cante del trovo por malagueñas.

Enraizados en el mundo sonoro de los cantes mineros, la discografía conserva también ciertos estilos, cuya paternidad se atribuye a troveros míticos como Pedro el Morato o el Pajarito.

De todos ellos hemos hablado a lo largo de estas páginas, presentando, además, en transcripción musical muchos de ellos. Todo ello con el objetivo de resaltar la estrecha relación que tradicionalmente ha existido -y que no debiera perderse- entre el mundo del trovo y el cante de las minas.

\section{Bibliografía}

BARCELÓ ARNeO, Andrés (s/f). Cartageneras: artículos, canciones, tangos, carceleras y cantares originales y populares. Cartagena: Imprenta Briasco.

BLAS VeGA, José (1973). Temas flamencos. Madrid: Editorial Dante.

BONMATí LIMORTE, Casimiro (1988). Los trovos. Narria: Estudios de artes y costumbres populares, $n .^{\circ} 49-50$, pp. 39-45.

CASAl MARTíneZ, Federico (1948). Folklore cartagenero. Cartagena: Imprenta Carreño.

CAstillo RodrígueZ, José (1923). Algo de mi vida: un viaje a la Corte de España. Murcia: Tipografía Sánchez.

CAstillo RodríGuez, José (1954/1994). Anecdotario retrospectivo Marín-Castillo: escrito original del poeta trovero José Castillo Rodríguez [prólogo y edición: Luis Díaz Martínez]. Lorca: D.L.

CENIZO, José. (2007). Con pocas palabras: coplas flamencas. Sevilla: Signatura, 2007. 


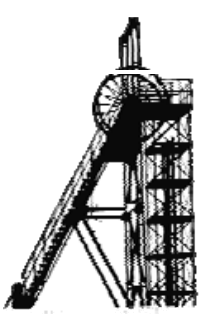

CROS, Fulgencio (Recop.) (1989). La carpeta de Pencho Cros: letras de cante. Madrid: Luike-Motorpress.

CHAVES ARCOS, Rafael y KLIMAN, Norman Paul (2012). Los cantes mineros a través de los registros de pizarra y cilindros. Madrid: Gráfica Varona

García Cotorruelo, Emilia (1959). Estudio sobre el habla de Cartagena y su comarca. Madrid: Imprenta de S. Aguirre Torre.

GARCíA GÓMEZ, Génesis. (1993). Cante minero, cante flamenco: una interpretación sociocultural. Barcelona: Anthropos - Murcia: Editora Regional de Murcia.

Gelardo Navarro, José (2007). Antonio Grau "Rojo el Alpargatero" hijo. El último de una saga flamenca. Almería: La hidra de Lerna.

GRANDE, Félix (1979). Memoria del flamenco. Madrid: Espasa Calpe.

Grima CERVANTES, Juan y TORRES CORTÉS, Norberto (1995). Pedro “El Morato". Navarro García, José Luis y Ropero Núñez, Miguel (Dirs.). Historia del flamenco (vol. II). Sevilla: Tartessos, pp. 125-129.

MANRIQUe LóPEZ, José y Alba VILlAGRÁn, Diego (1978). Los cantes de La Unión y Cartagena. Barcelona: Casa Regional de Murcia y Albacete.

Martín Ballester, Carlos; SOler DíAZ, Ramón; CASTRO BuendíA, Guillermo y GamboA, José Manuel (2016). Don Antonio Chacón. Madrid: Copyfer.

MARTín SALAZAR, Jorge (1998). Las malagueñas y los cantes de su entorno. Motril: Asociación Cultural Guadalfeo.

MARTínEZ TORNEL, José (1892a). Cantares populares murcianos. Murcia: Imprenta de "El Diario".

MARTíNEZ TORNEL, José (1892b). Cantares murcianos (remitidos). Murcia: Imprenta de "El Diario".

Murcia GaLiÁN, Juan Francisco y OrTEGA, José Francisco (2016). Cartagena, la copla y el cante. Revista de Investigación sobre Flamenco "La Madrugá", no. 13, pp. 179212. Recuperado de https://revistas.um.es/flamenco/article/view/278191.

Murcia Galián, Juan Francisco y OrtegA, José Francisco (2017). "Si vas a San Antolín": Murcia, la Niña de los Peines y el cante por cartageneras. Música Oral del Sur, n. 14, pp. 161-203. Recuperado de http://www.centrodedocumentacionmusicaldeandalucia.es/export/s ites/default/publicaciones/pdfs/si_vas_a_san_antolin_murcia_la_nin a_de_los_peines_y_el_cante_por_cartageneras.pdf.

NAVARRO GARCíA, José Luis (1989/2014). Cantes de las minas. Sevilla: Libros con Duende.

NoEl, Eugenio (1926/2007). Martín el de la Paula en Alcalá de los Panaderos. Sevilla: Extramuros [edición facsímil].

NúÑEZ DE PRADO, Guillermo (1904). Cantaores andaluces. Barcelona: Maucci. 
OCón, Eduardo (1874). Cantos españoles: colección de aires nacionales y populares. Málaga-Leipzig: Breitkopf \& Härtel.

Ortega CAstejón, José Francisco (2017). Cantes de las minas, cantes por tarantas. Murcia: Editum.

Ortega CAstejón, José Francisco; SOler Guevara, Luis; Ruiz García, Rafael y Gómez Alarcón, Antonio (2019). Malagueñas, creadores y estilos. MurciaMálaga: Editum-UMA Editorial.

Puig CAmpillo, Antonio (1953). Cancionero popular de Cartagena. Cartagena: Imprenta Gómez.

RocA, Ángel (1976). Historia del trovo: Cartagena-La Unión (1865-1975). Cartagena: Athenas Ediciones.

RUIPÉREZ VERA, Juan (2005). Historia de los cantes de Cartagena y La Unión. Cartagena: Editorial Corbalán.

SÁEZ, Asensio (1965). Libro de La Unión: biografía de una ciudad alucinante. Murcia: Imprenta Belmar.

TOMÁs LOBA, Emilio del Carmelo (2015). El trovo murciano: historia y antigüedad del verso repentizado. Propuesta didáctica para la Educación Secundaria Obligatoria (tesis doctoral). Murcia: Universidad de Murcia. Recuperado de https://digitum.um.es/digitum/handle/10201/47888.

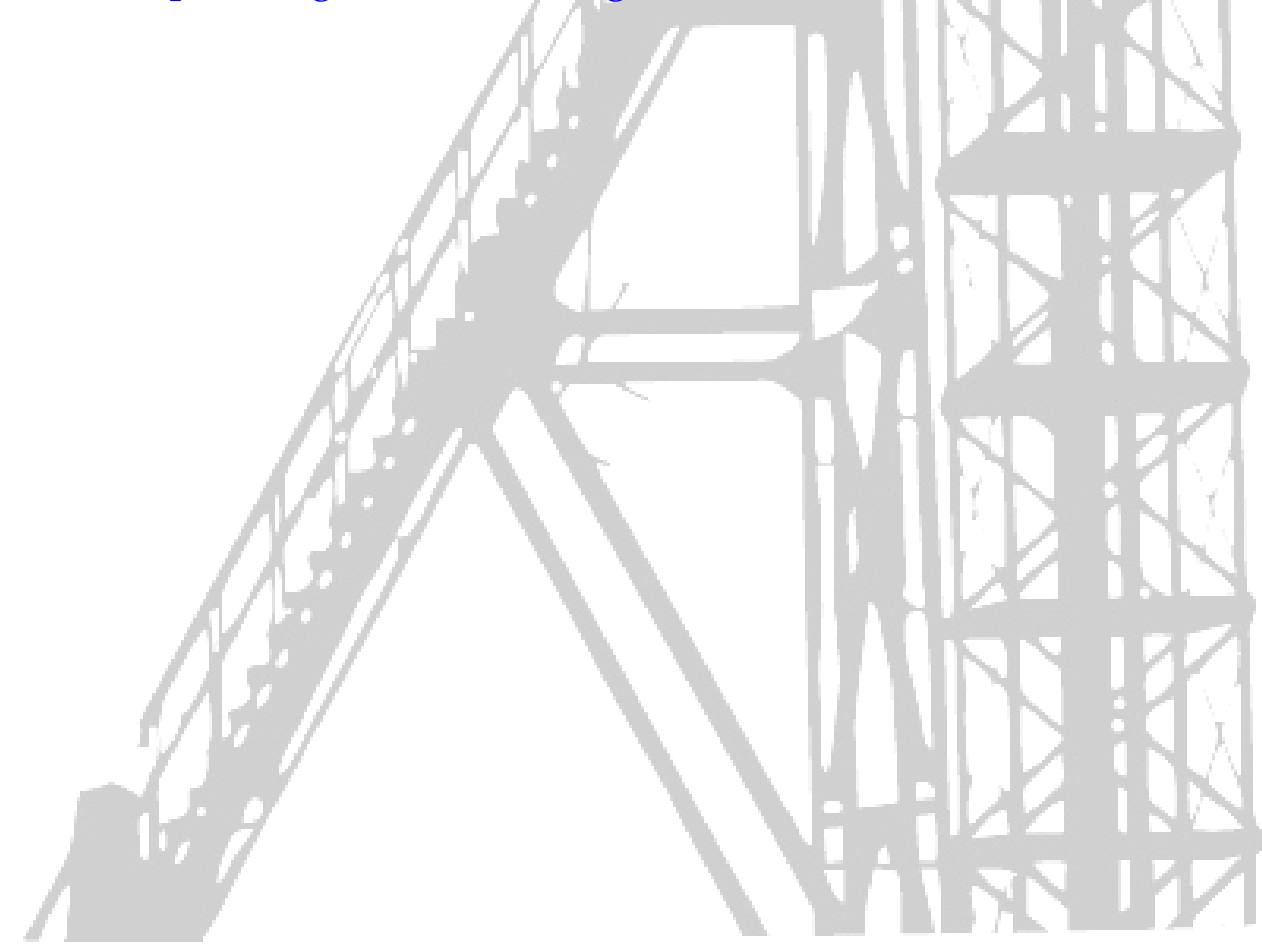




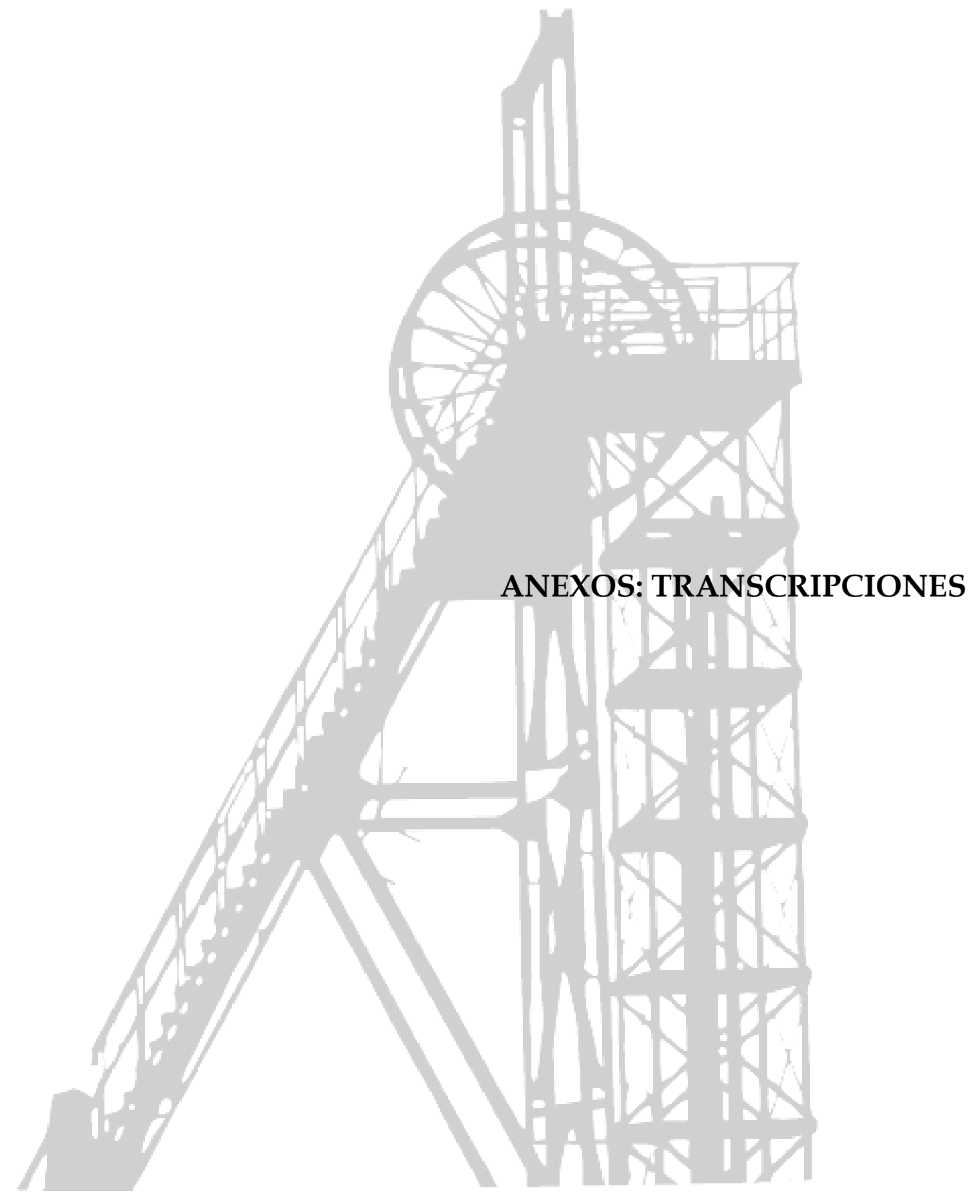




\section{Sobre las transcripciones}

Hemos optado por presentar todas las transcripciones en el tono estándar de Mi para, de este modo, facilitar el cotejo entre ellas.

No anotamos el ritmo de la línea melódica, detallando sólo las alturas. Hemos adoptado, en cualquier caso, unas convenciones que sirven de orientación en cuanto al movimiento rítmico. Así, los sonidos de duración estándar se representan con cabeza redonda de tamaño normal. Una cabeza cuadrada indica que la nota tiene mayor duración. Por el contrario, si su valor es breve, lo señalamos con cabezas redondas de tamaño reducido.

Empleamos ligaduras con el fin de precisar la articulación melódica: del grupo de notas englobadas por debajo, la última es la más importante, recayendo sobre ella el acento rítmico.

Las comas altas indican una cesura, habitual al finalizar un tercio, si bien pueden aparecer también en el transcurso del mismo, ya sea porque el cantaor necesita tomar aire, o bien por cuestiones expresivas.

Si una nota lleva alteración accidental, el efecto de ésta se mantiene hasta cambiar de línea, a menos que un becuadro indique lo contrario. 


\section{Soy piedra que en la terrera}

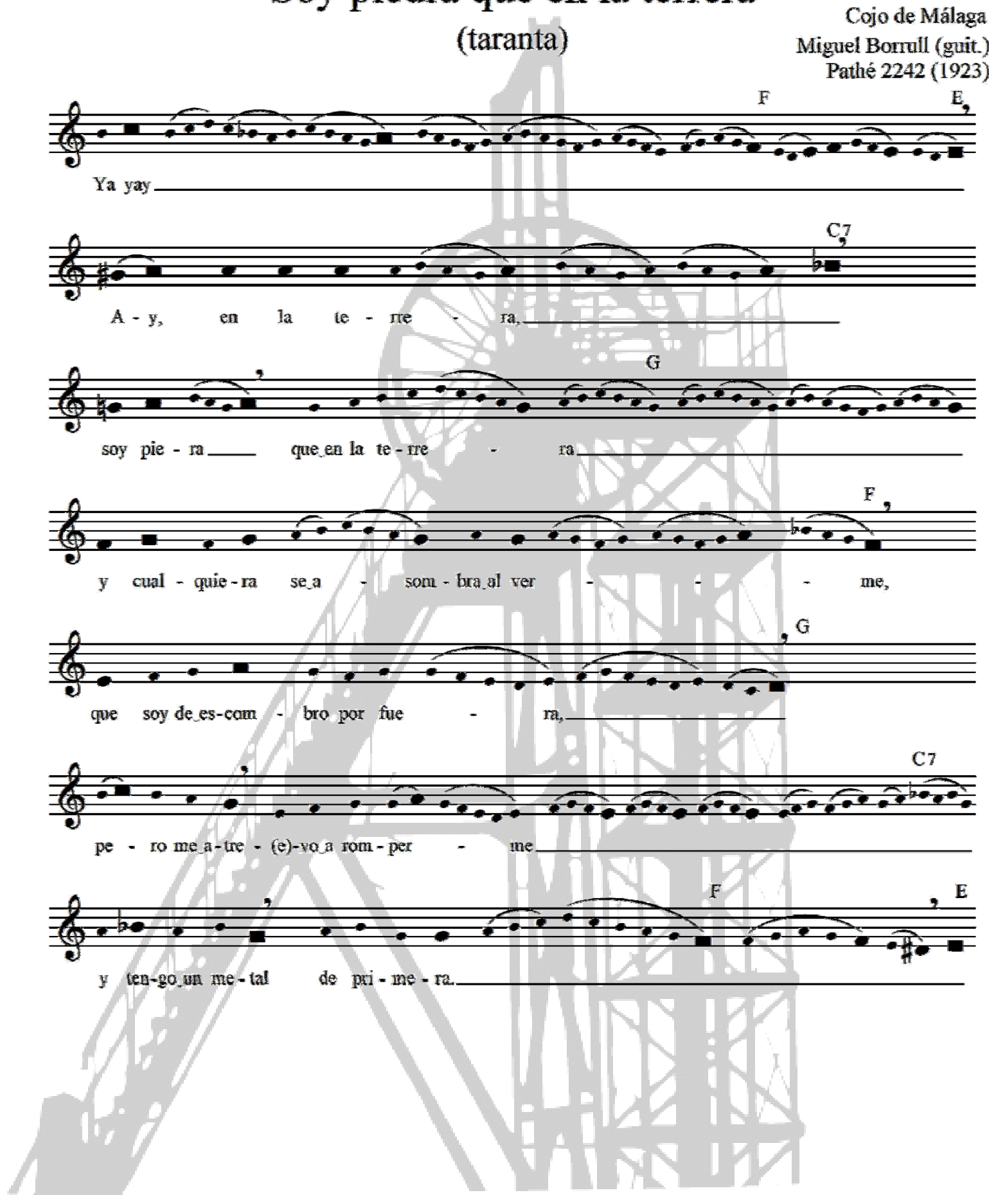

Oase F. Ontega 


\section{Para poderte guardar (malagueña del trovo)}

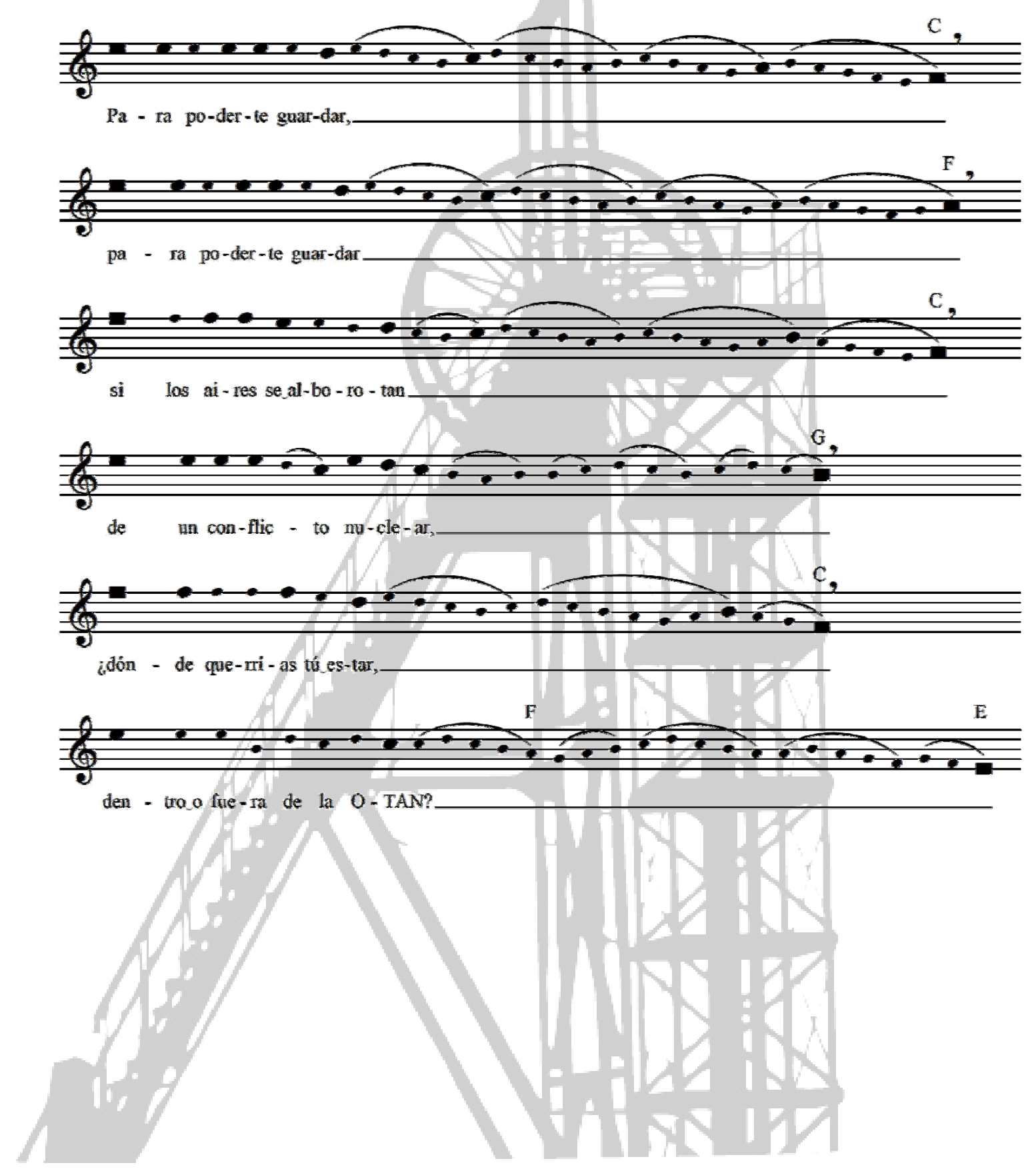

OJosé F. Ortega 


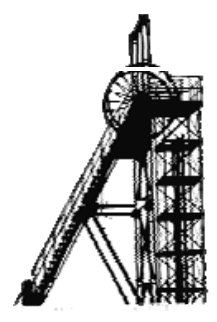

Sólo te confesaré (malagueña del trovo)

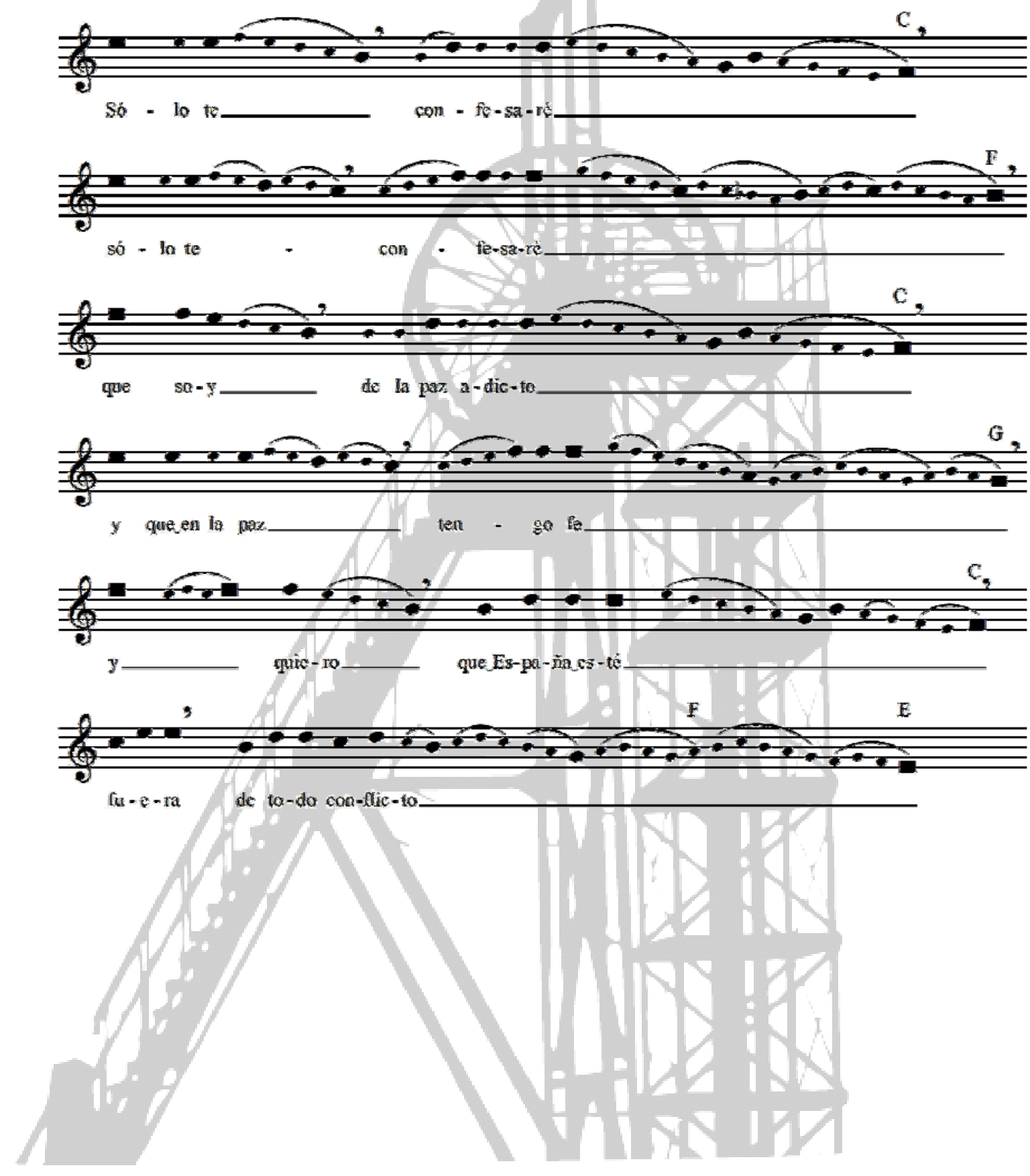

Mos: F. Ortega 


\section{Conejo, con tu saber (malagueña del trovo)}

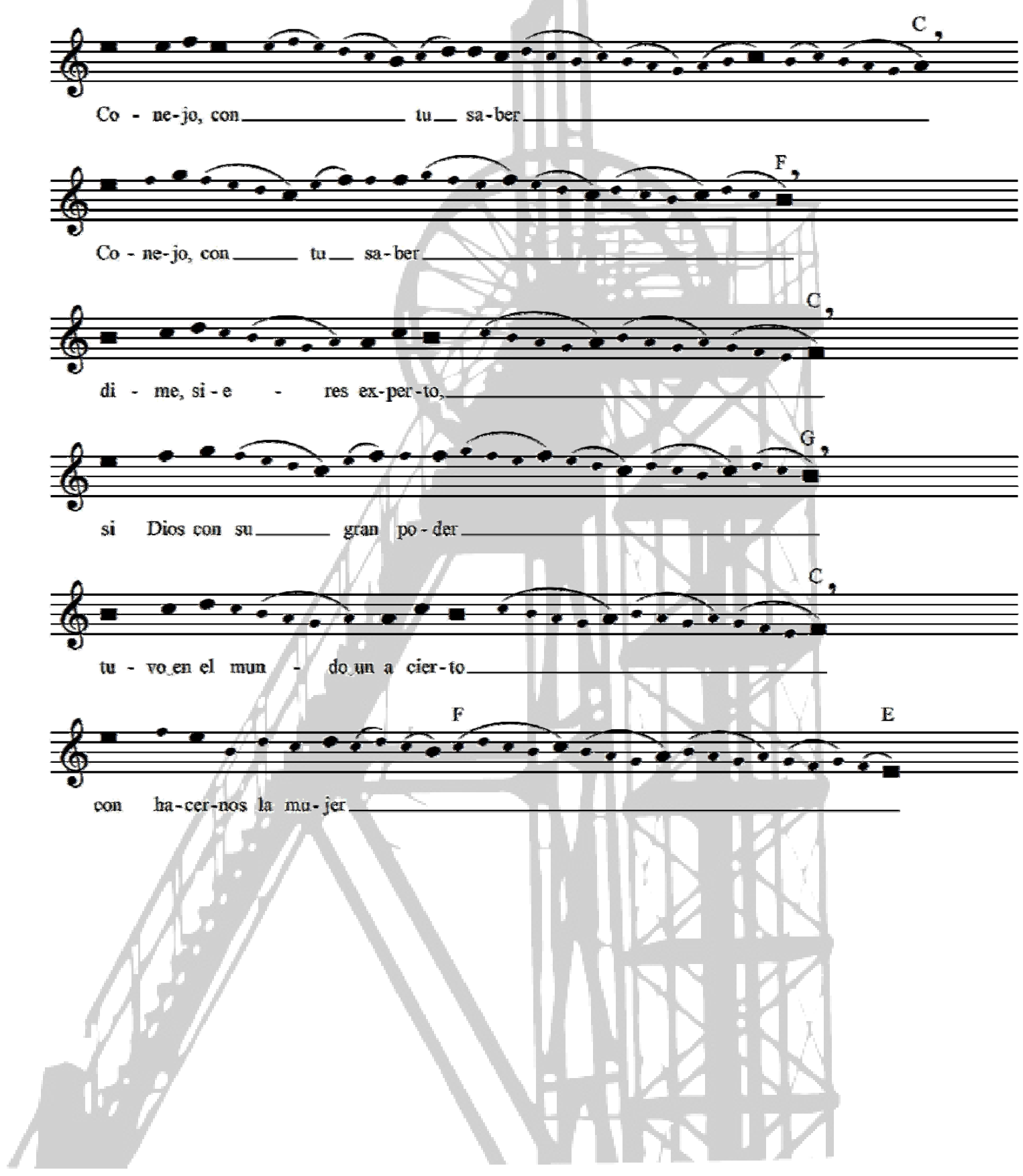

OJosé F. Ortega 


\section{Yo te diré un sí rotundo (malagueña del trovo)}

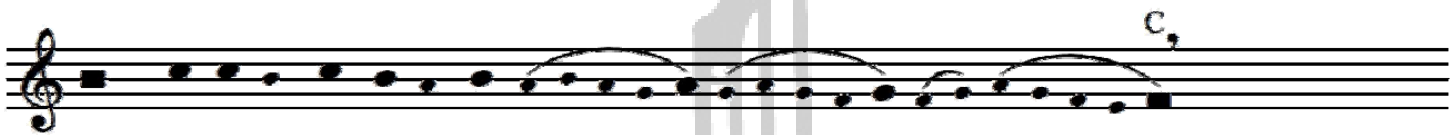

Ay, yo te di-ré un sí ro-tun-do

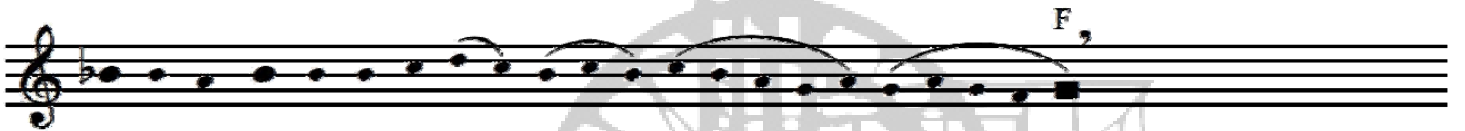

yo te di-ré un sí ro-tun - do

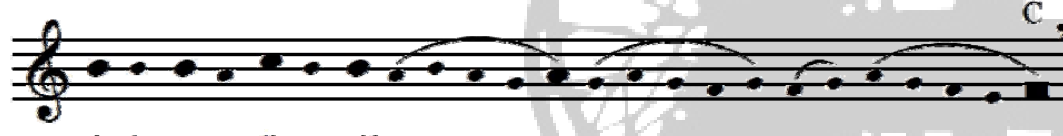

sin lu-gar a dis-cu-sión

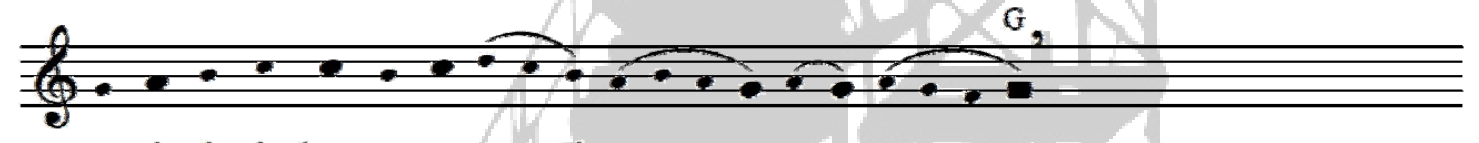

y $\sin d u-d a r-l o$ un se-gun - do

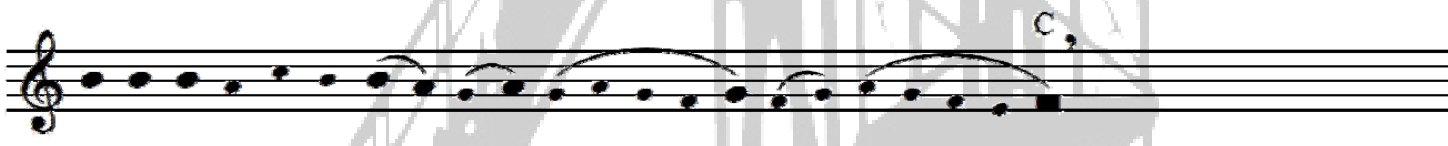

to-das las mu-je-res son

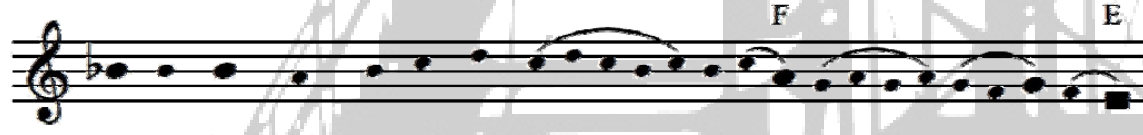

lo me-jor que hay en el mun-do

OJosé F. Orlega 


\section{Fueron a Quitapellejos} (cante del trovo)

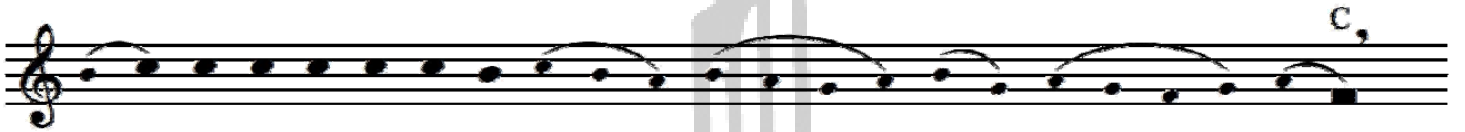

Fue - ron a Qui-ta-pe-He - - - jos

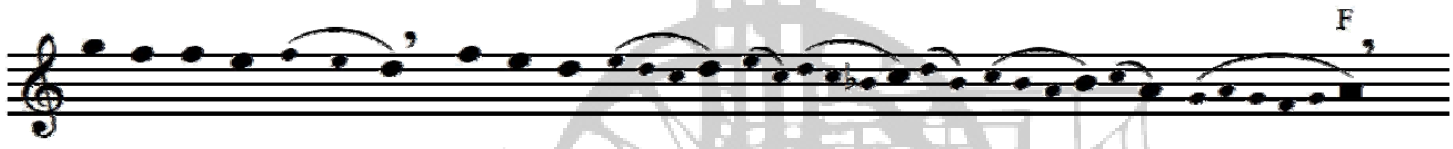
los de San An - tonio A-bad
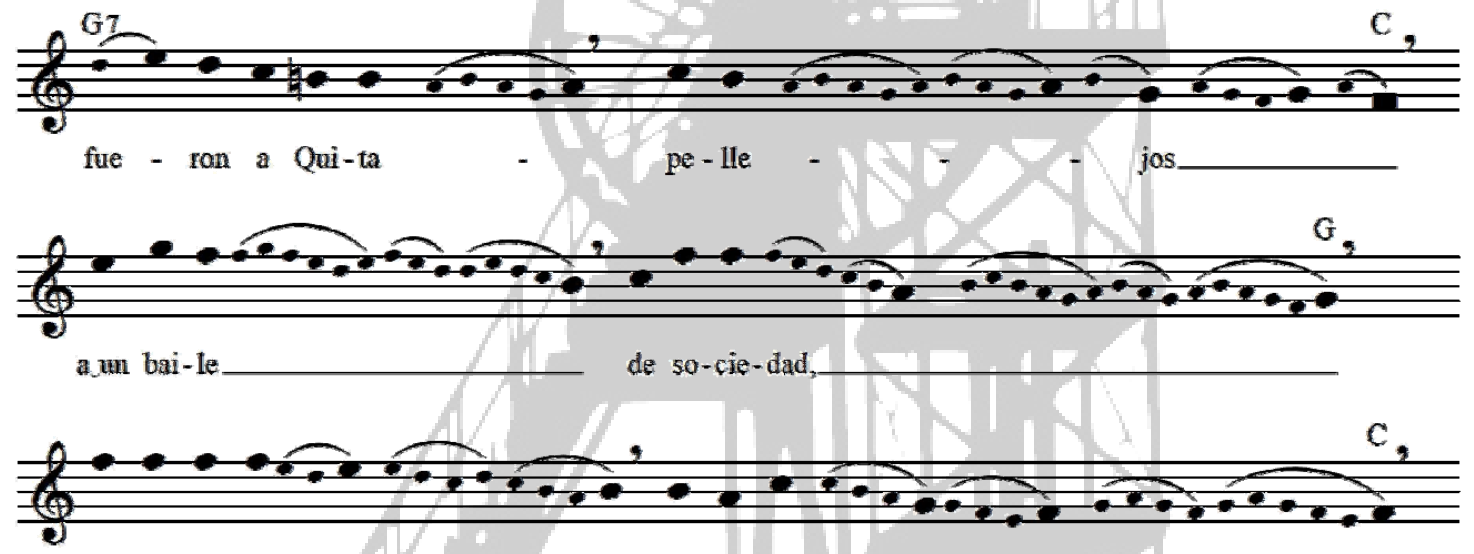

por lle-var el tra-je vie
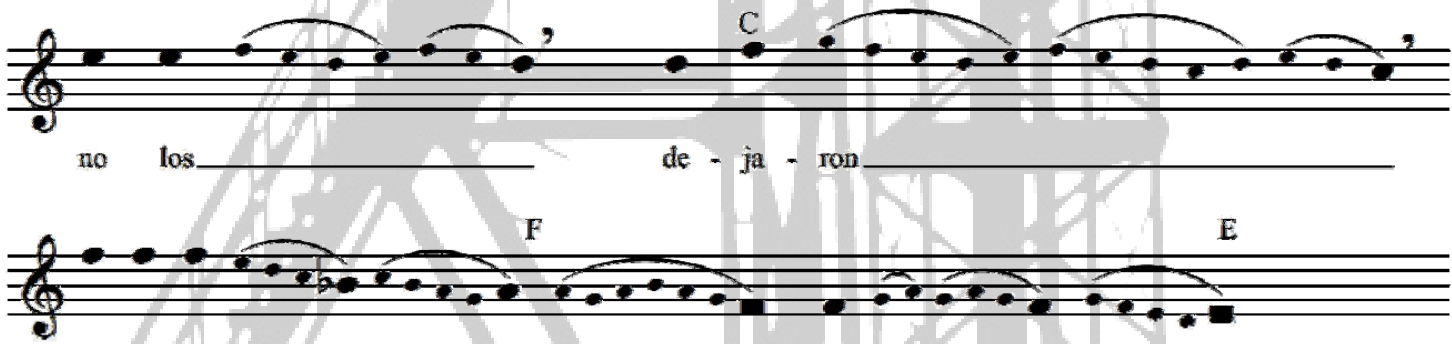

(on) en - trar,

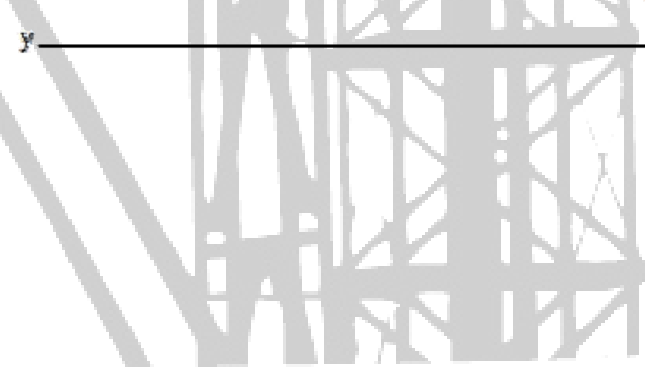

Aose F. Ontega 


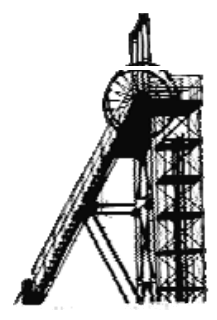

\section{Fueron a Quitapellejos} (taranta)

Niño de la Huerta Manolo de Badajoz (guit.)

Odeón 182.661 (1929)
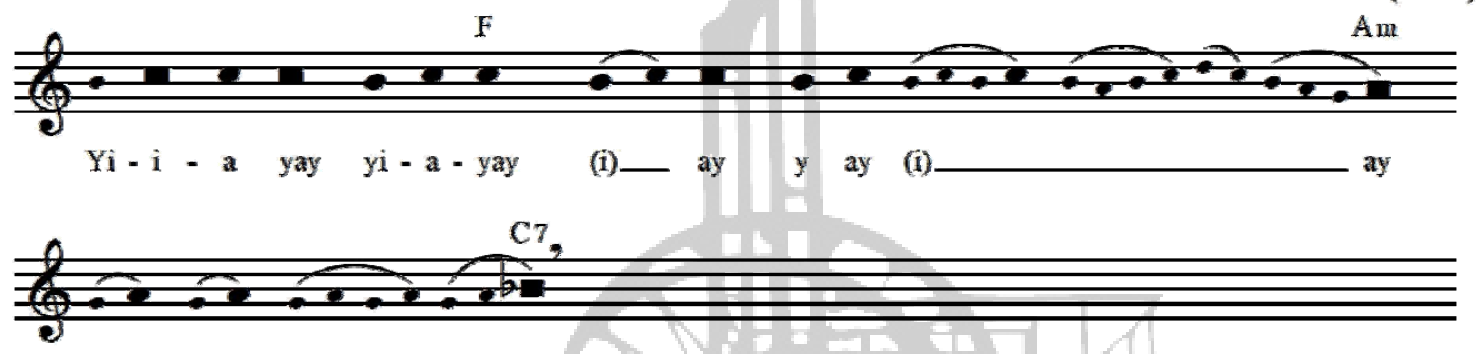

$\mathrm{i}-\mathrm{a}$
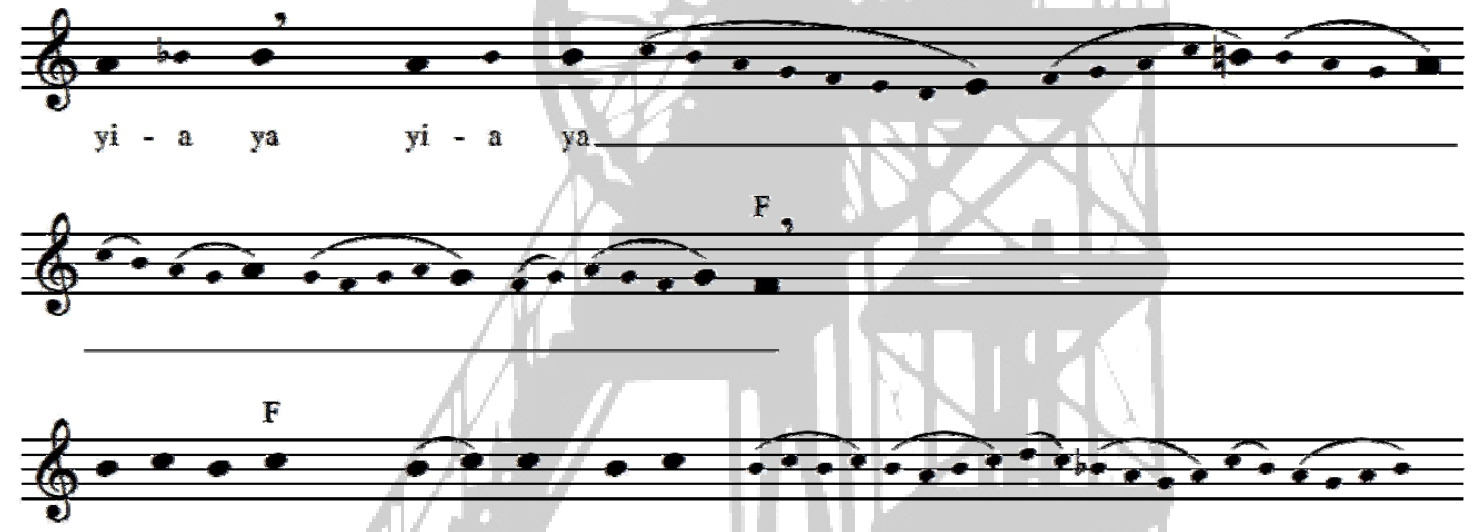

yi - a yi - ay

(i) _ ay

(i) ay
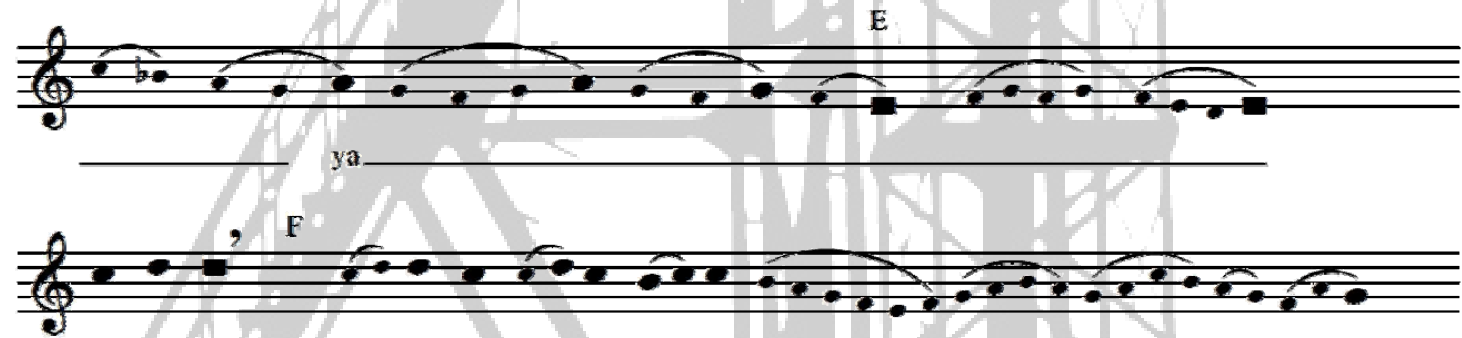

Que fue-ron

(on) a Qui-ta - pe - Ile - jos

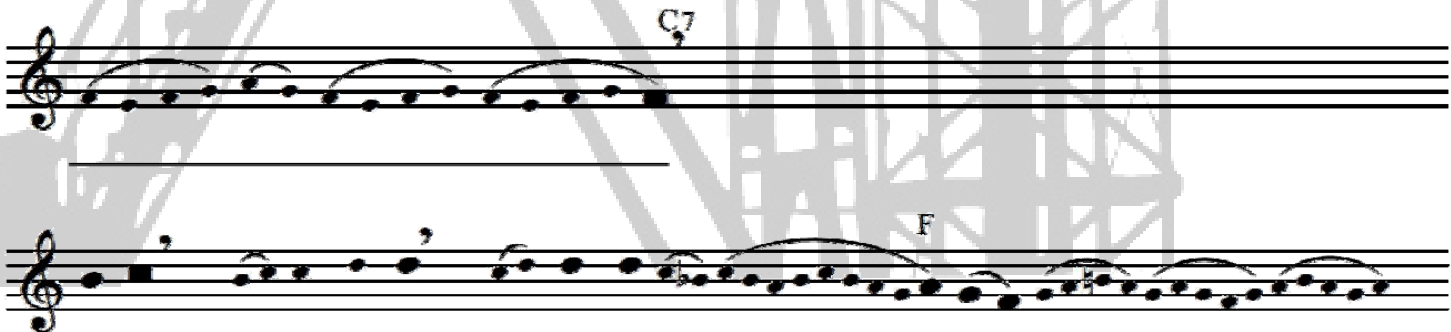

los de (e) San An-io - (o) nio A-bad

Gos F. Ontesa 
2

Fueron a Quitapellejos
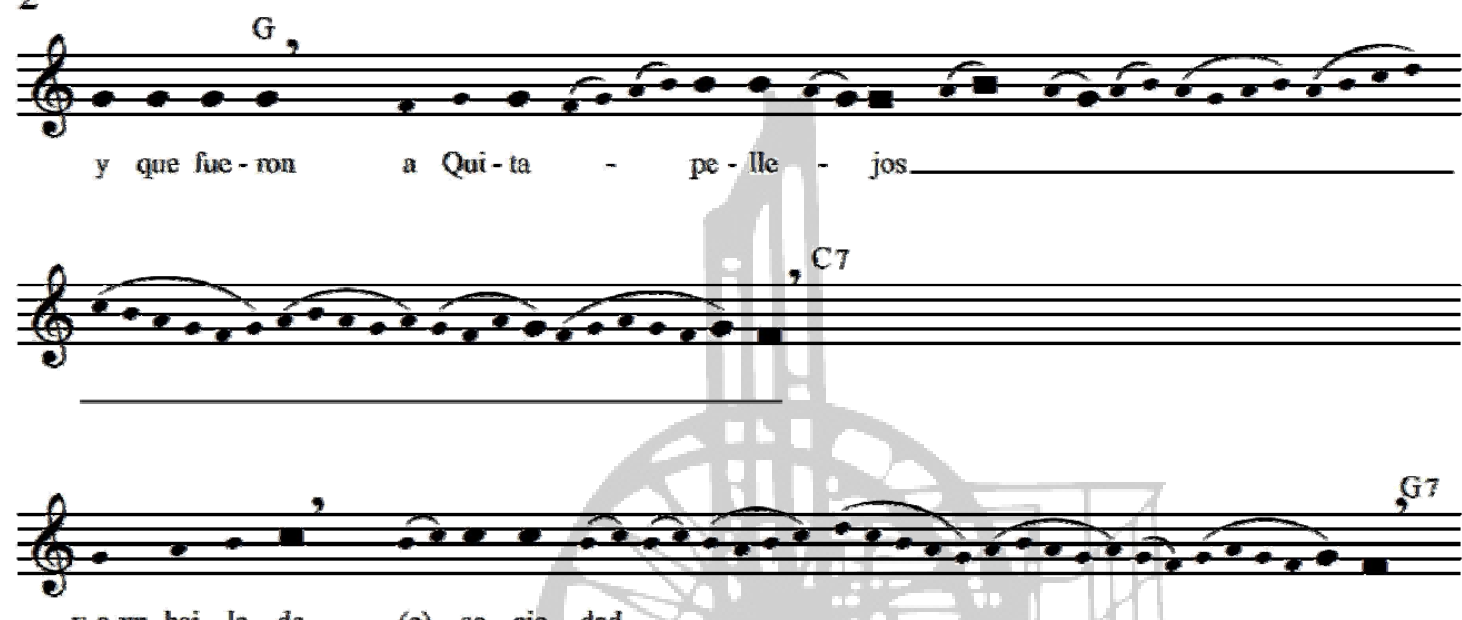

y.a un bai - le de (e) so-cie - dad

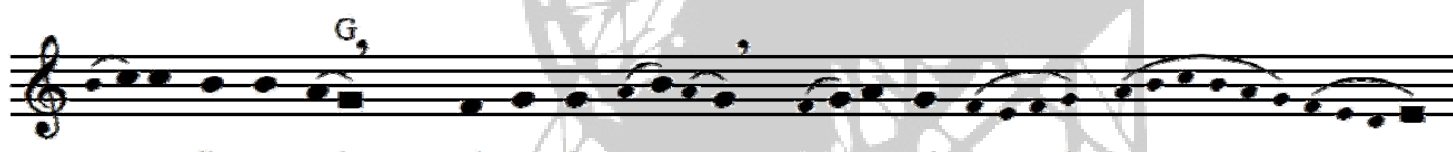

pe - ro lle-va - ban el tra - je

(e) tan vie - jo

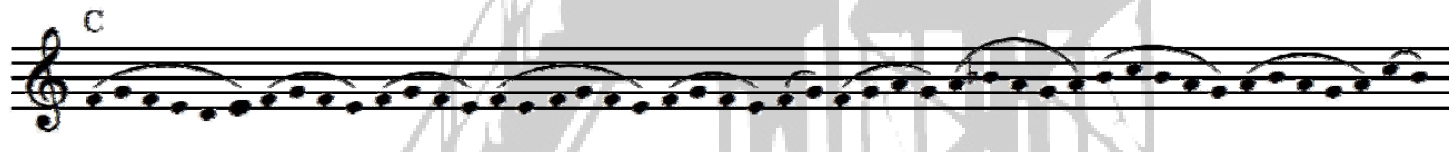

C?
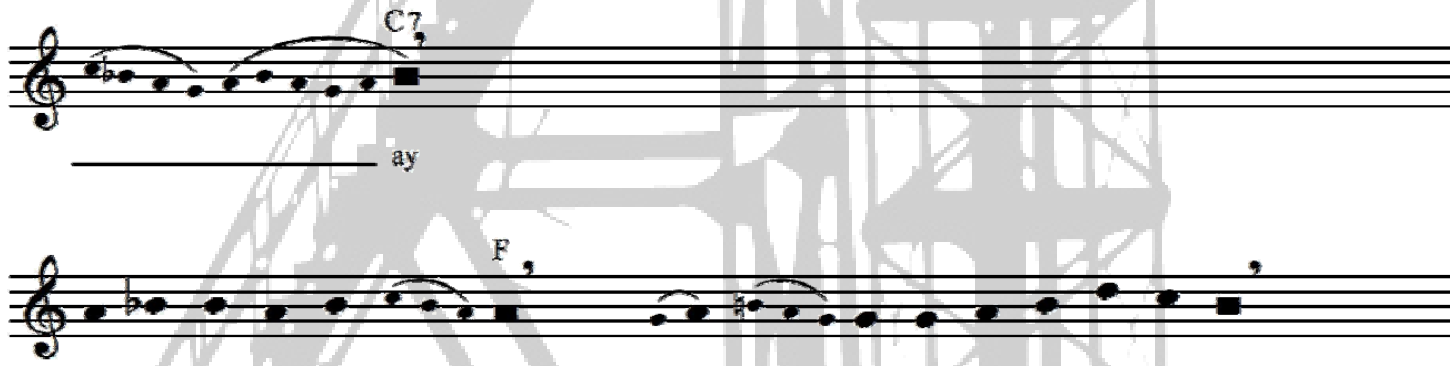

que no los de - ja $\quad$ ron (on)_ en-trar, en-trar los po-bres

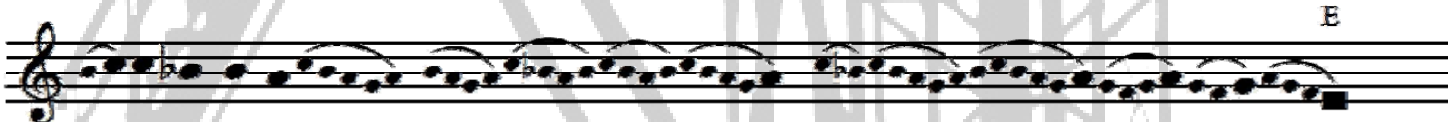

(e) no pu-die-rem 


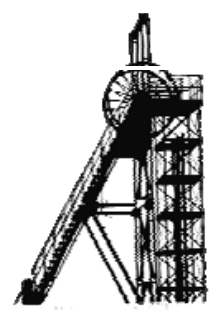

\section{Soy del reino de Almería (mineras)} Clave-Hisparox 18-1380 $5(1977)$
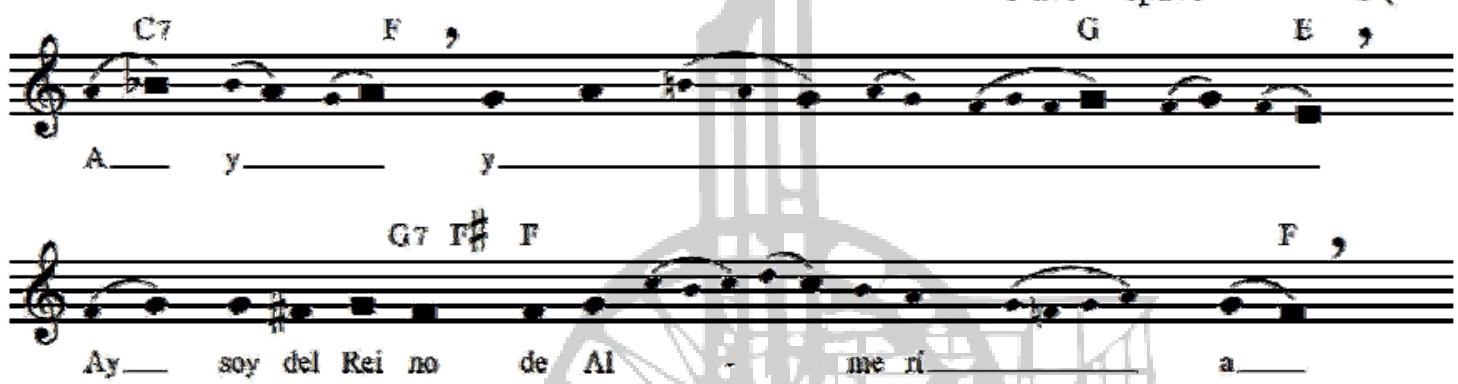

C.7

$\mathbf{F F}$

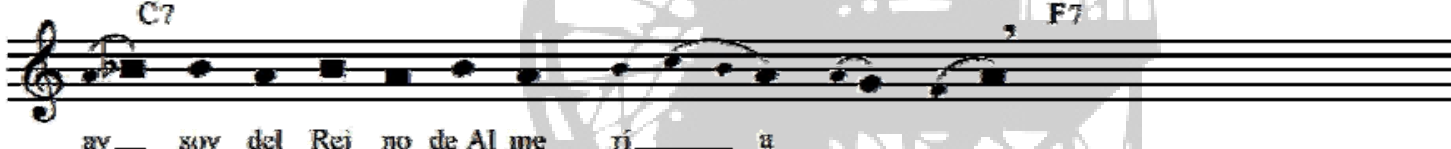

ay- sury dal Rei no de.Al me ní_ \&

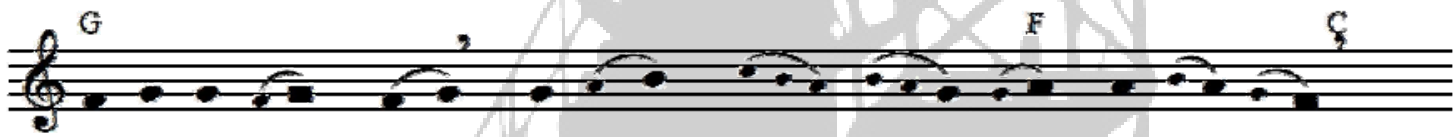

en don-dg na - cen (en)__ los tem - pra - nos

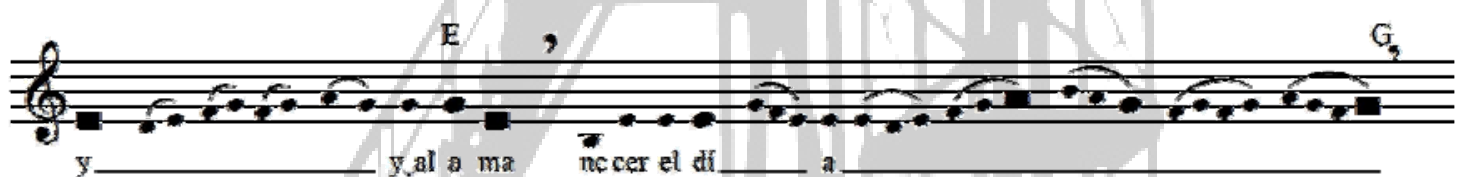

G.

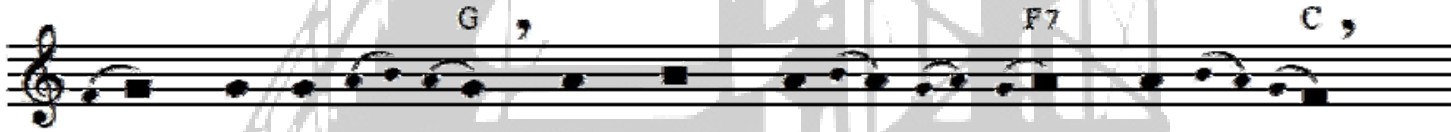

ay_ meen cuen__ tro a $\mathrm{Pe}$ dro__ el Mo_ na to
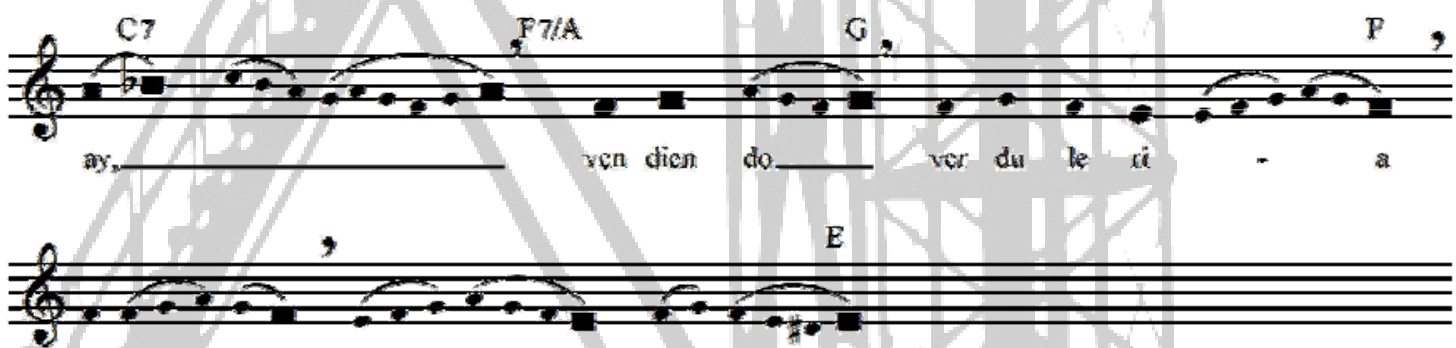

(a)

Mose F. Ontega 


\section{Yo soy el mejor trovero}

(cante del Morato)

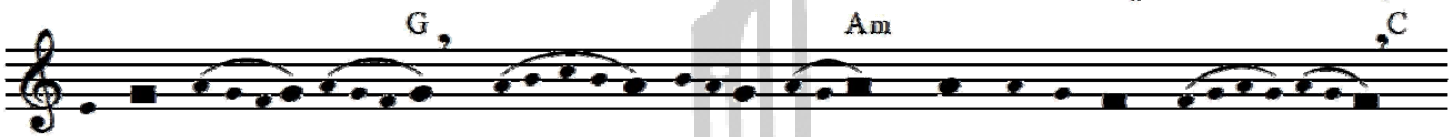

Me $11 a-\operatorname{man}$

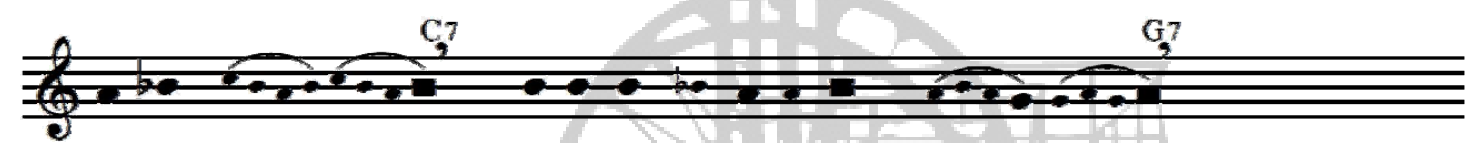

so $-\mathrm{y}$
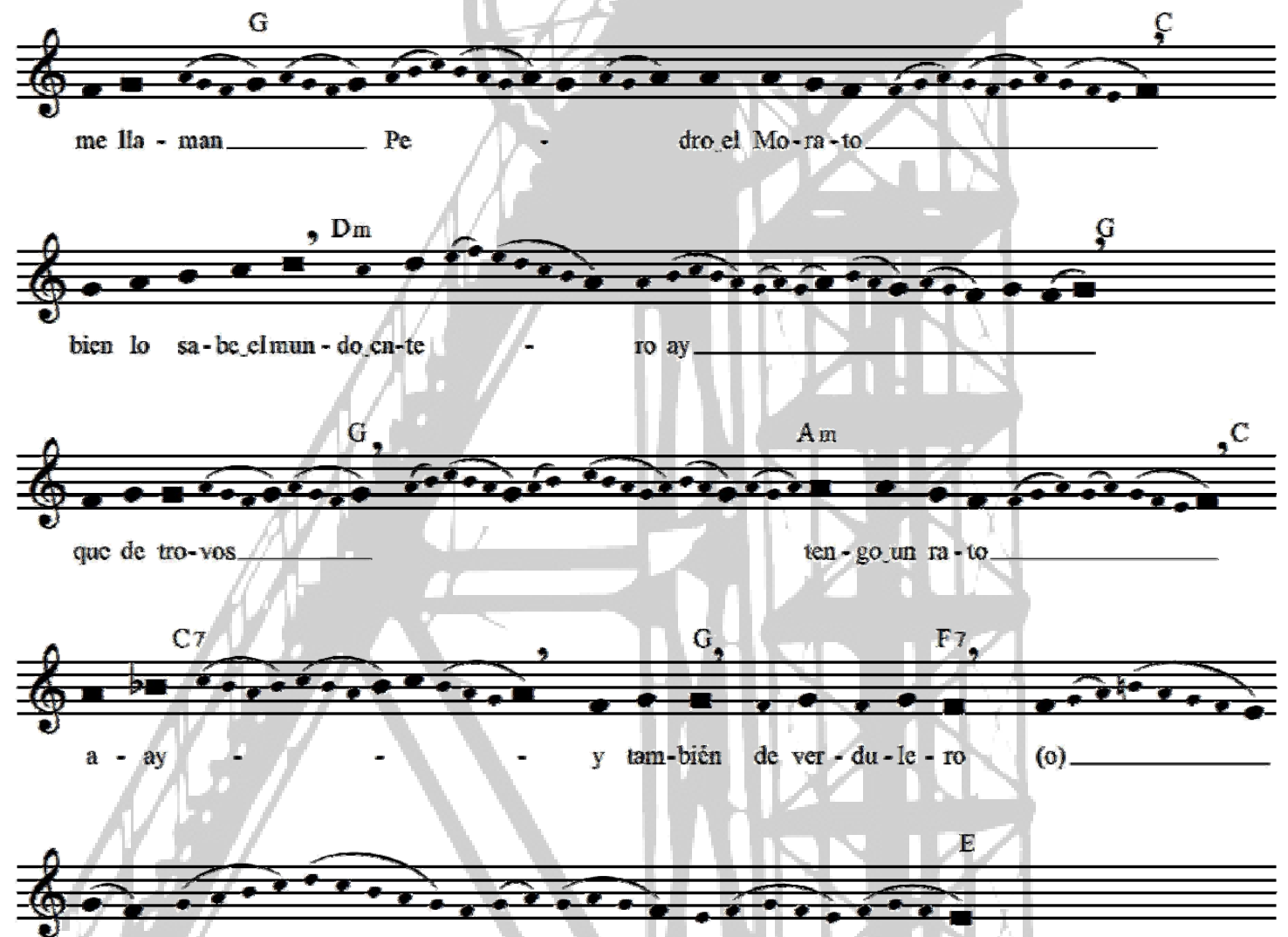

OJosé F. Orlega 


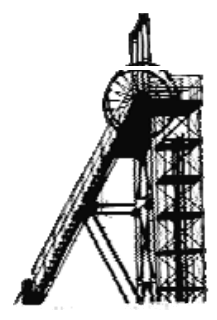

\section{Vaya tela de verano}

(taranta de Pedro el Morato)

Hispavox?-HH 10-346/47 (1973)
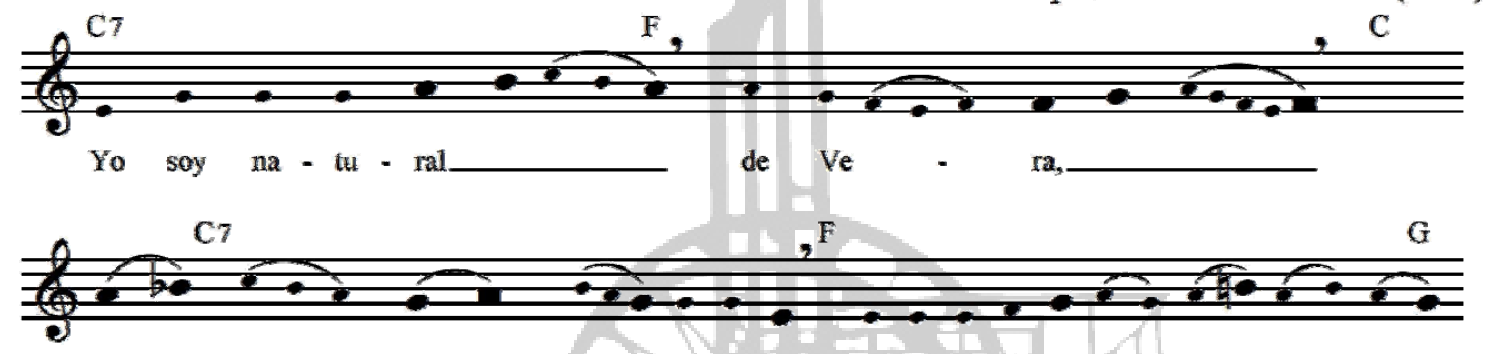

a - ay_me lla-man Pe-dro el Mo-ra
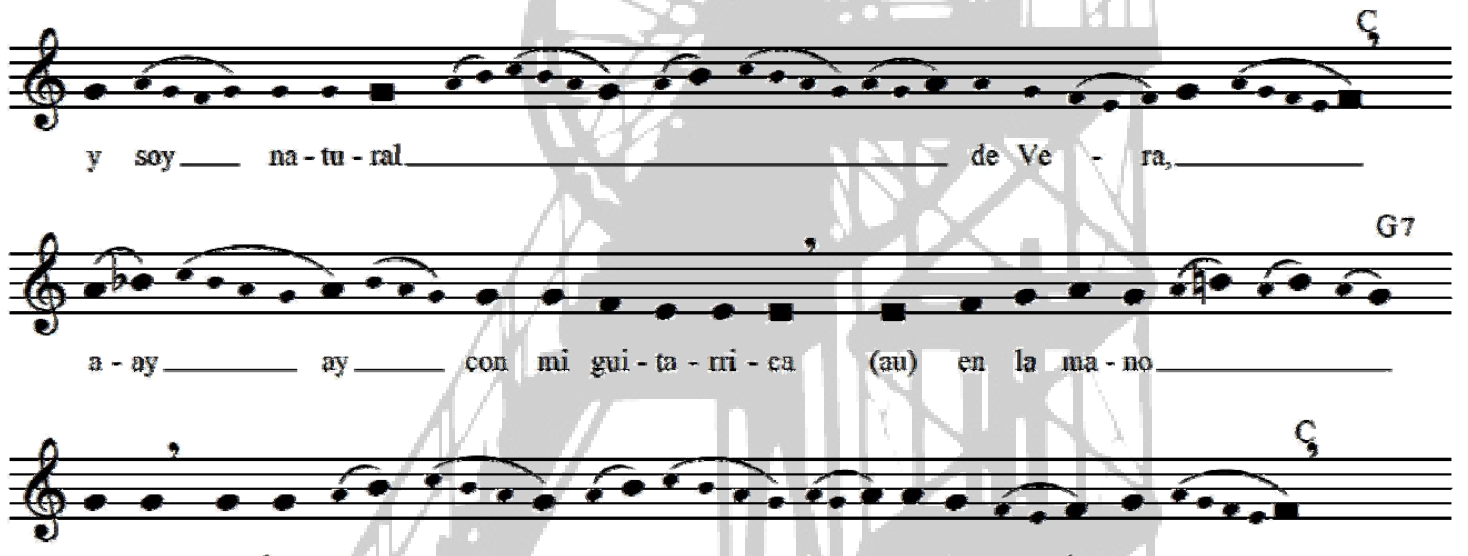

va-ya te-lay ven _ _ _ _ $\quad$ ven - ga te
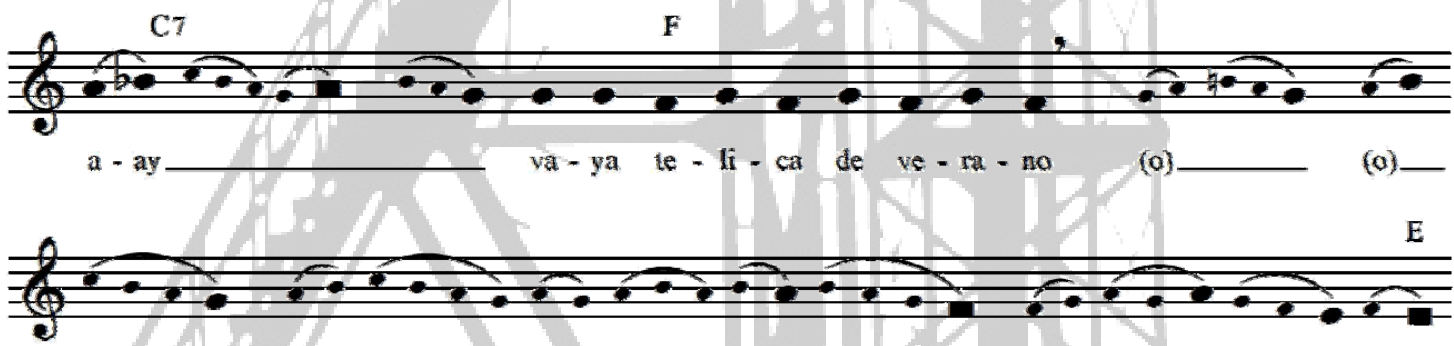

(0)

OJosé F. Ortega 


\section{Con la Emperatriz}
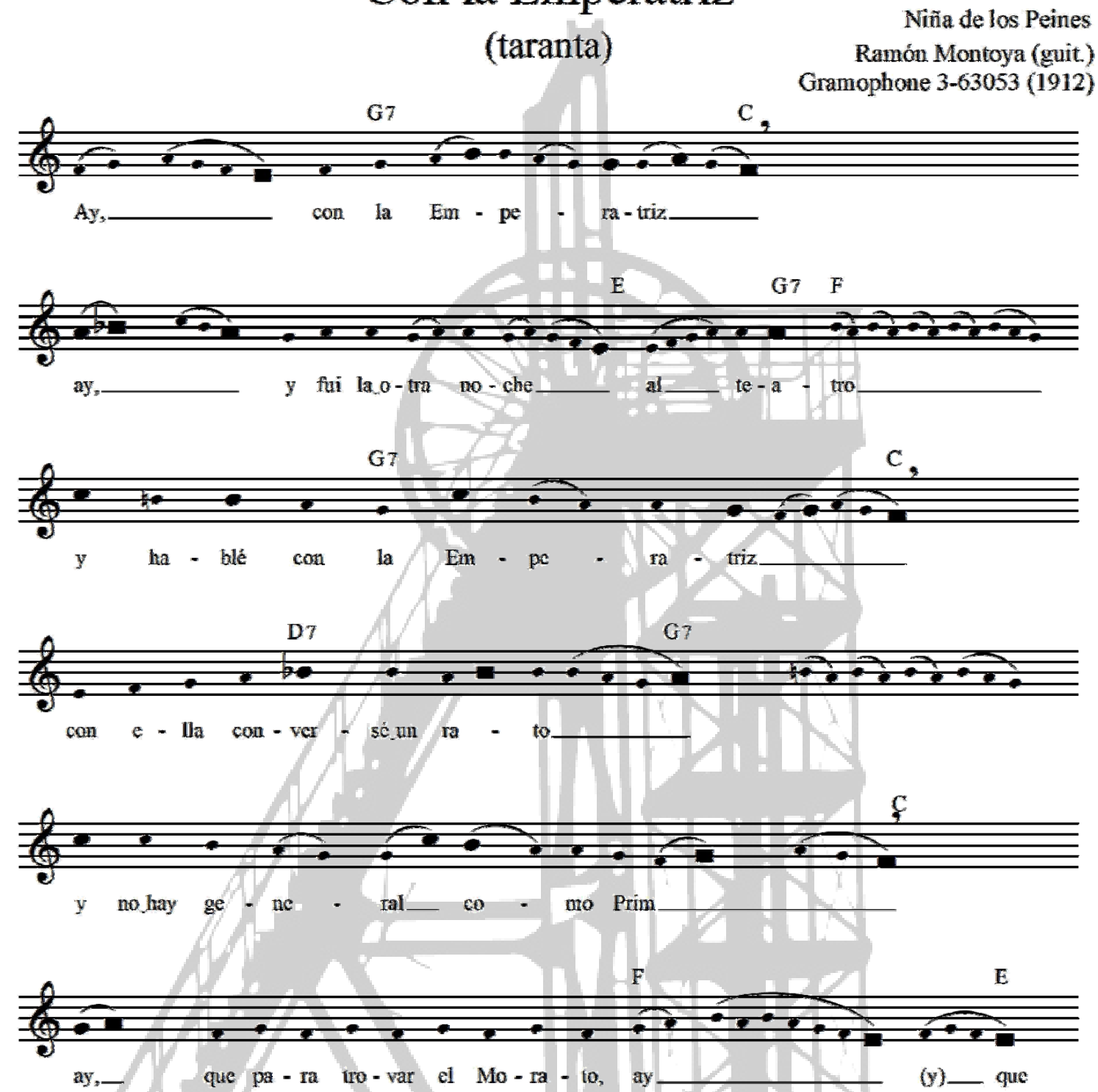

OJosé F. Orlega 


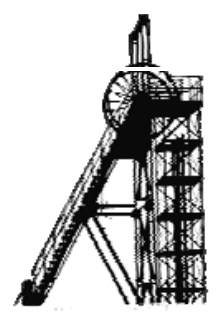

\section{El carretero}

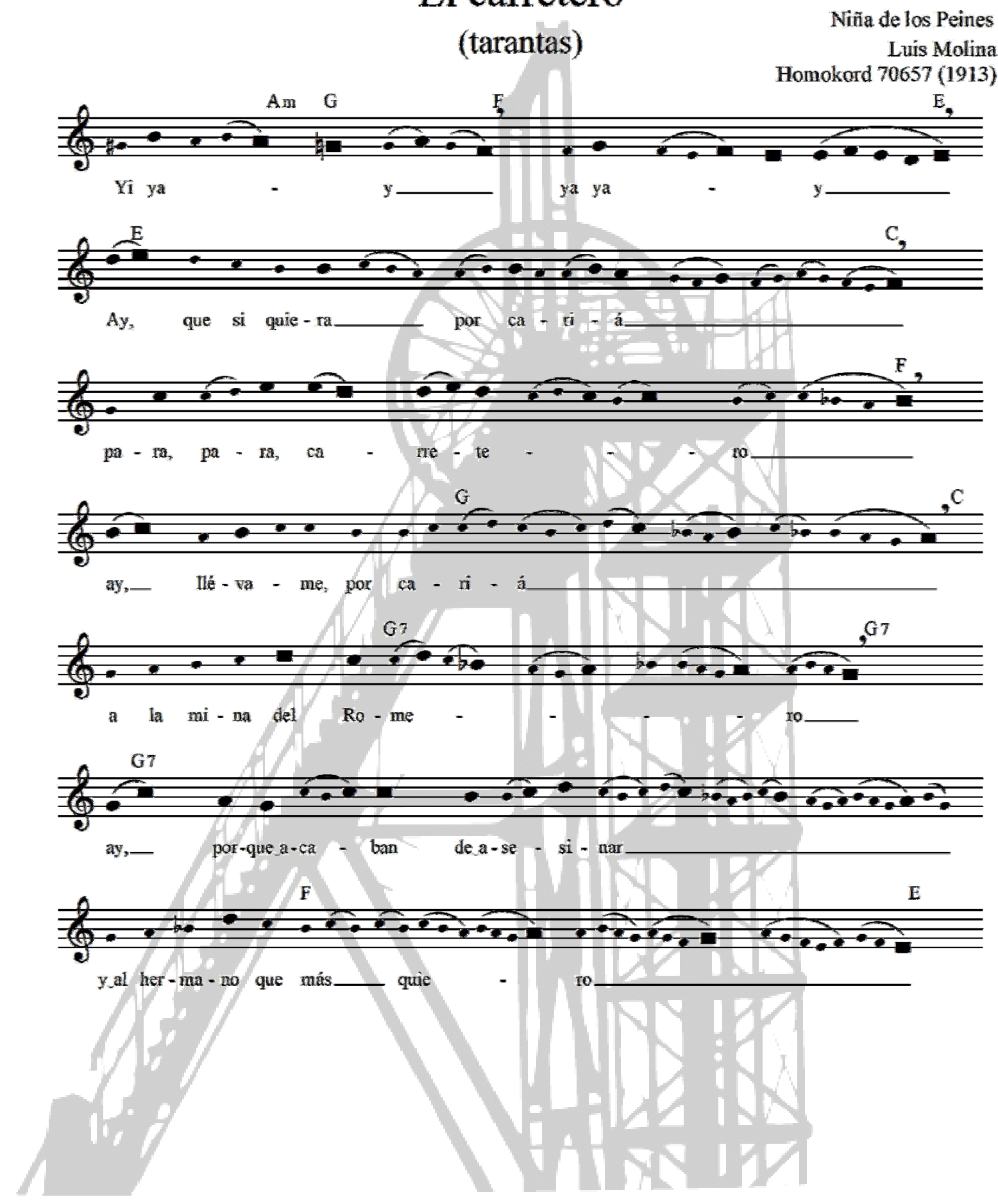

OJosé F. Orlega 


\section{A las minas del Romero}

(cantes de "Pedro el Morato")
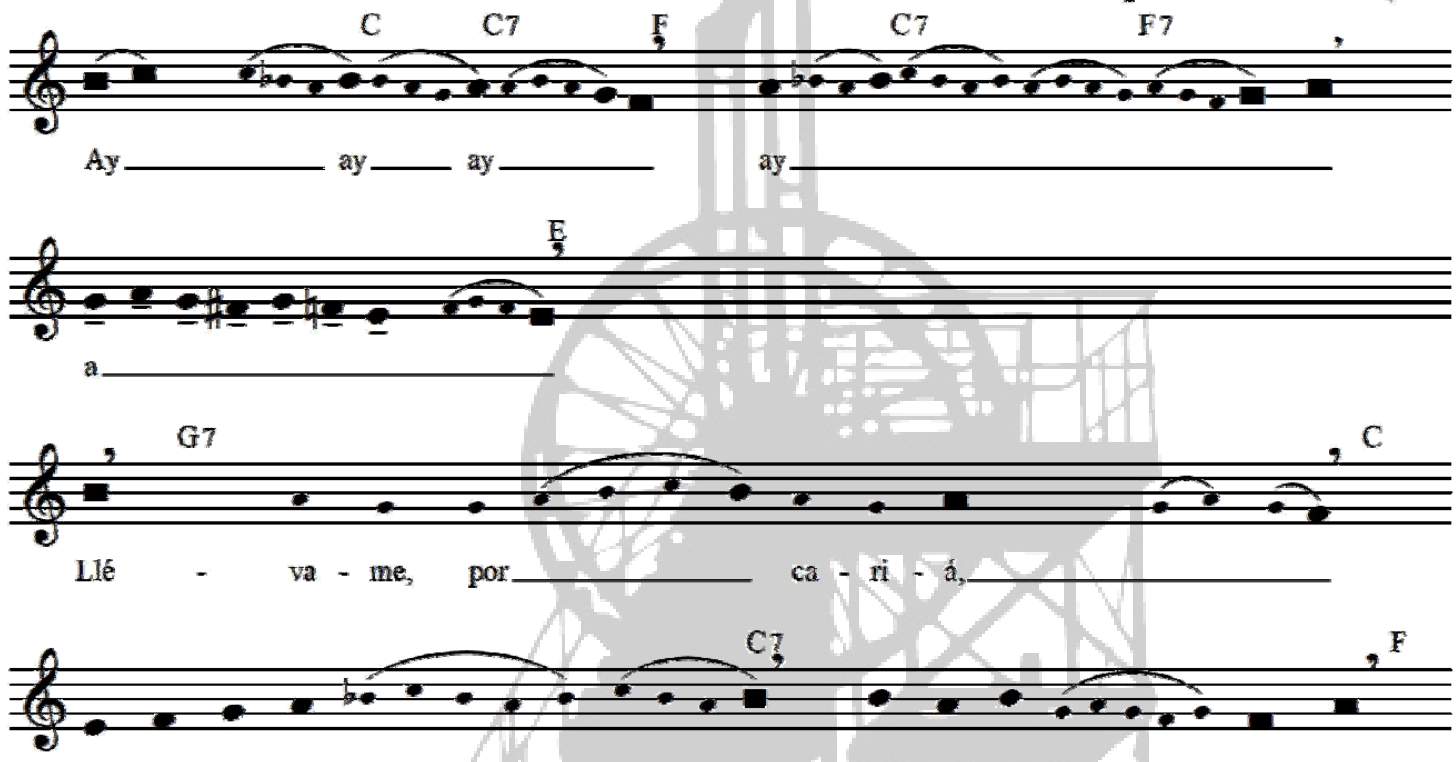

$\mathrm{ca}$ - ree - te - ro

ca - rre - te - ro,
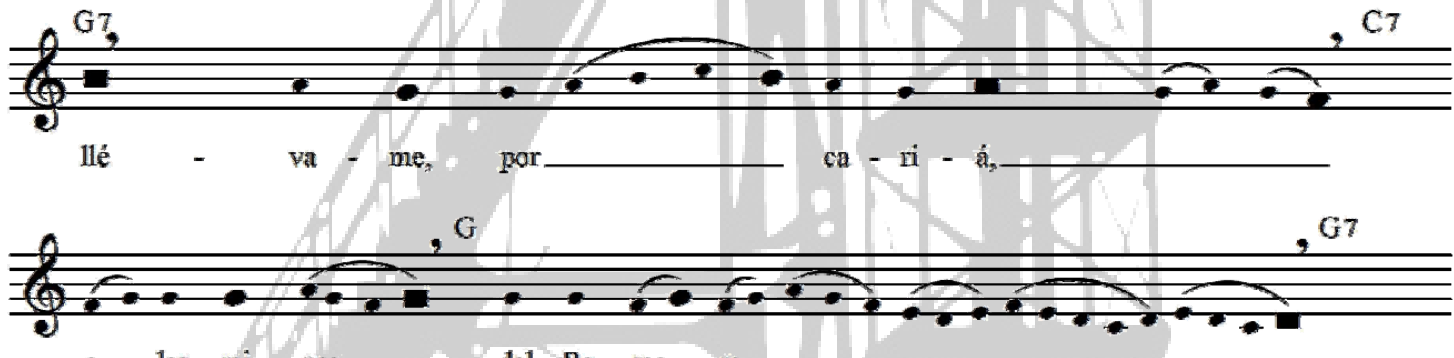

a_ las mi - nas

del Ro - me - ro

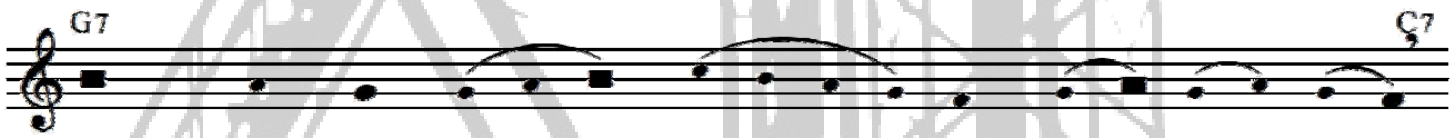

quea - ca - ban de a
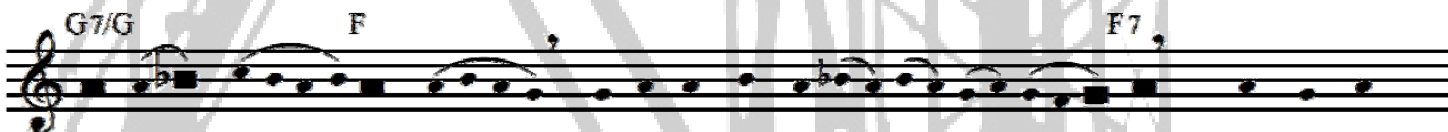

ay:

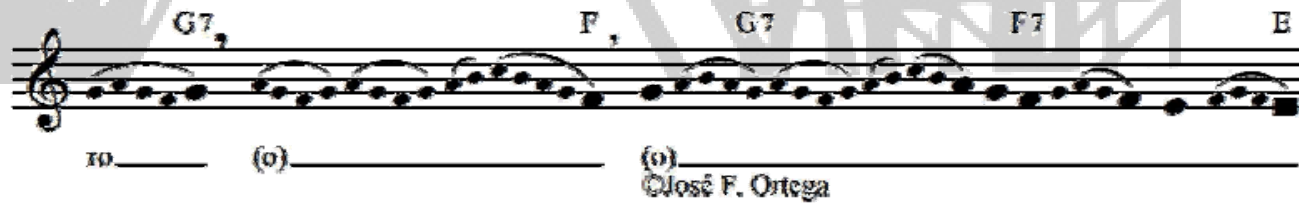




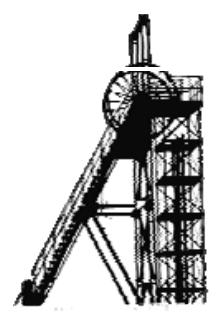

\section{Llévame por cariá}

(rondeña o fandango de cierre)
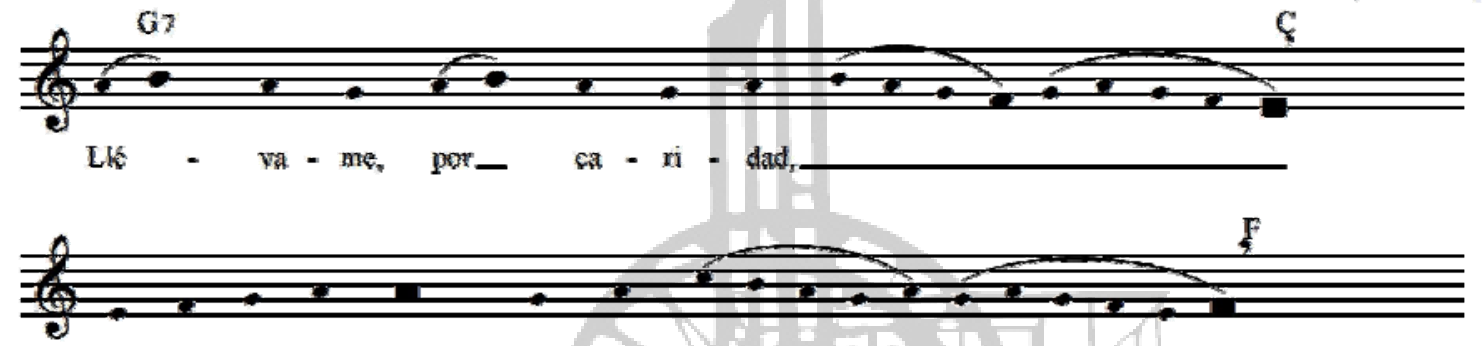

$\mathrm{ca}=\mathrm{rme}=\mathrm{te}=\mathrm{mo}, \mathrm{ca}=\mathrm{me}-\mathrm{tc}$

ro

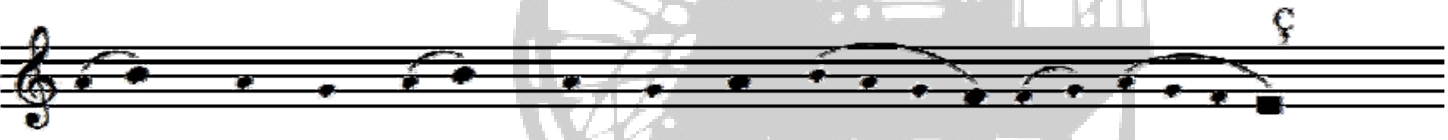

Ilé - va - me, por- ca - ri - dad

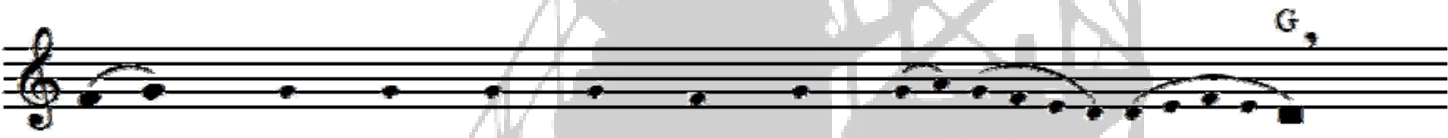

a_las mi - aas del Ro - me

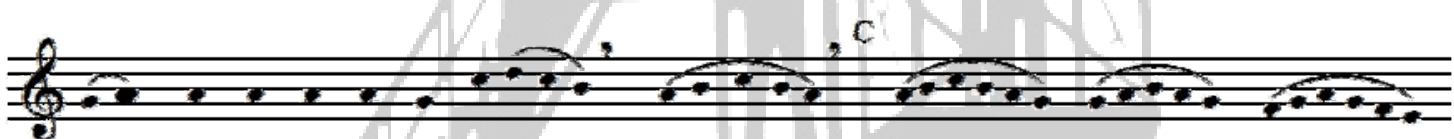

por - que a-ca-ban de ma-tor_ ay,

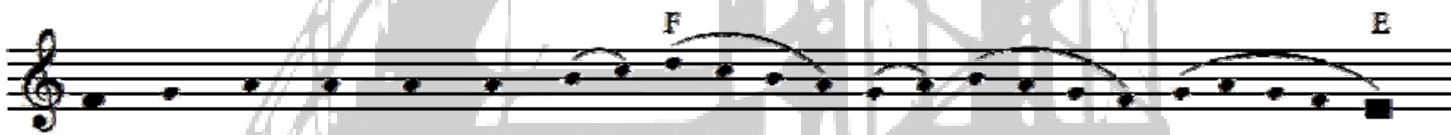

al ber - ma - no que mas quie

Mose F. Ortega 


\section{Soy tartanero de fama}

(cante del Pajarito)

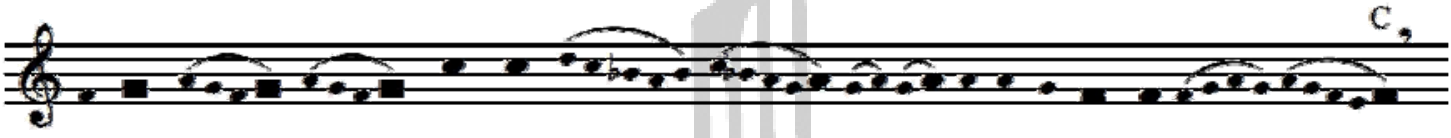

Yoles - choal can - - - - tegle-guí-a, ay

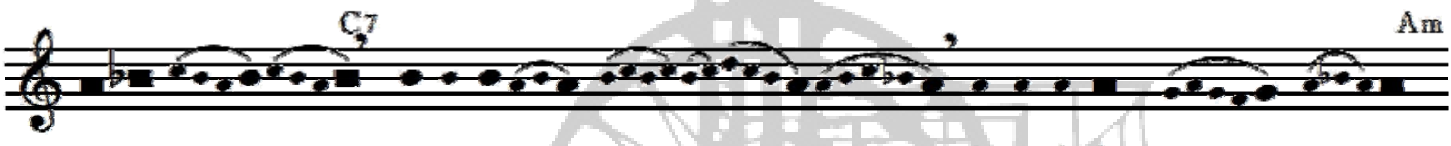

so $-\mathrm{y}$

tar-ta-ne

(e)-ro de fa

ma

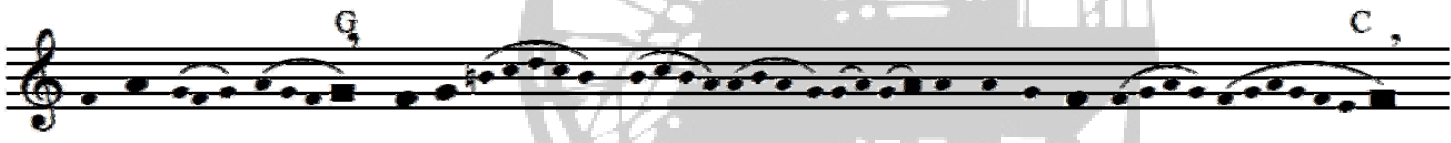

y pon-go al can

te a-le-gri-a

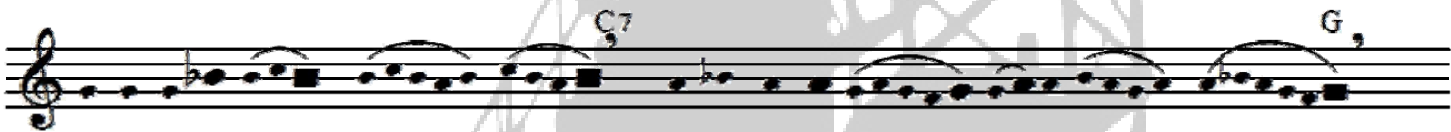

el Pa-ja-ri - io

a mi me lla

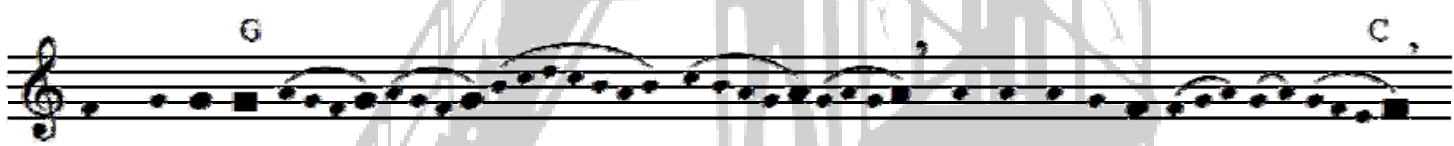

no hay en to - as

las He-rre-ri-as

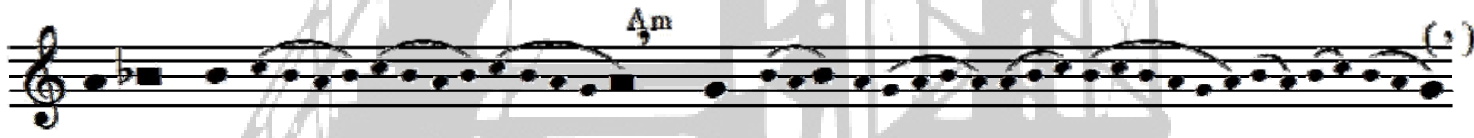

$a=a-u y$

quien ten - ga

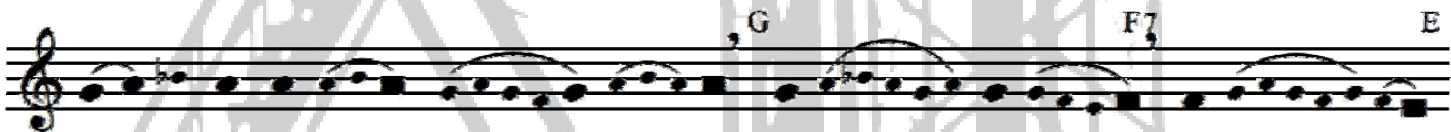

(ai) - me-jor bar-ta

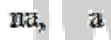

$\mathrm{a}-\mathrm{y}$

Oase F. Ontega 


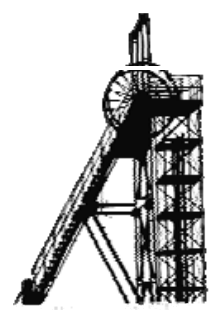

\section{Que vuela sobre la mar} (taranta del puerto)

Niño de la Calzá

Niño Ricardo (guit) Columbia V $9370(1945)$
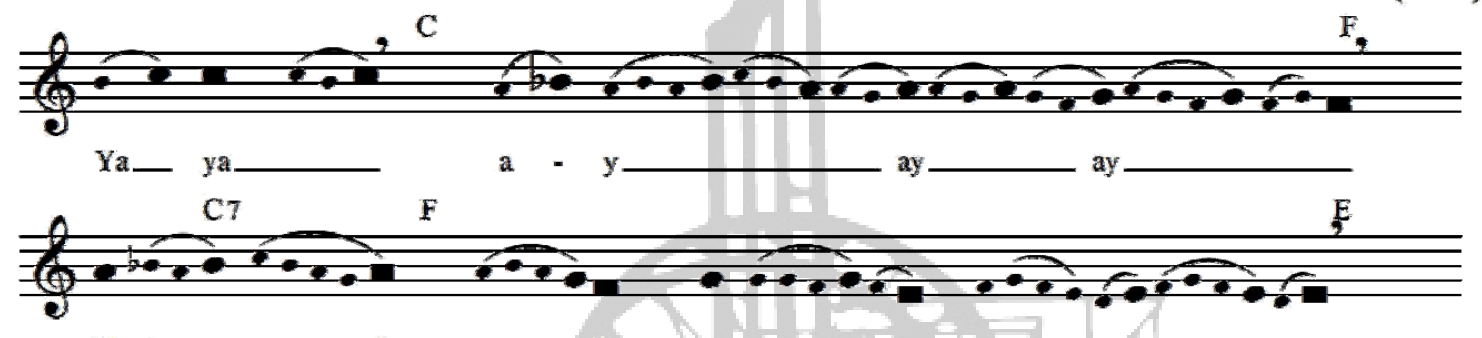

ya $-y$ - a

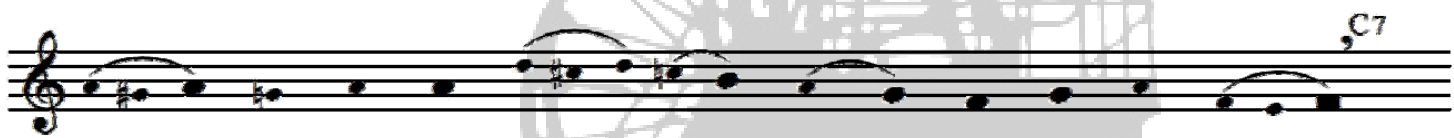

$A y=$ que vue - Ia so

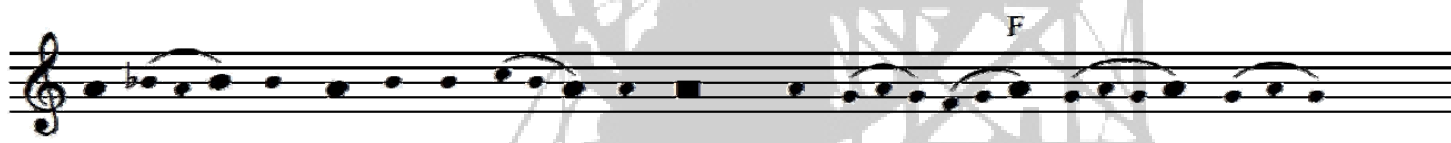

so - y co-moel a - ve-
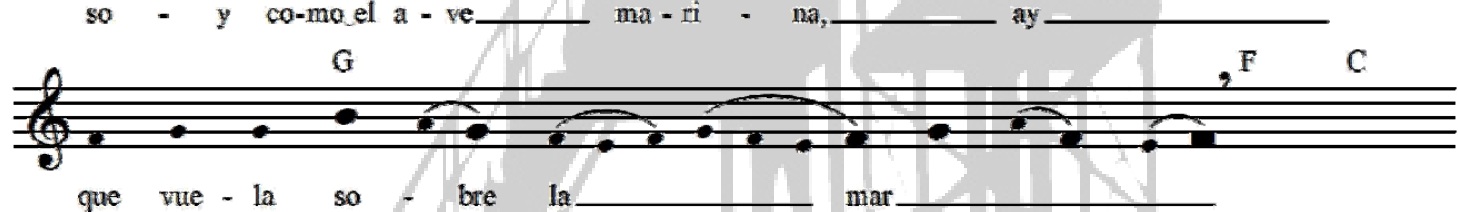

que vue - la so

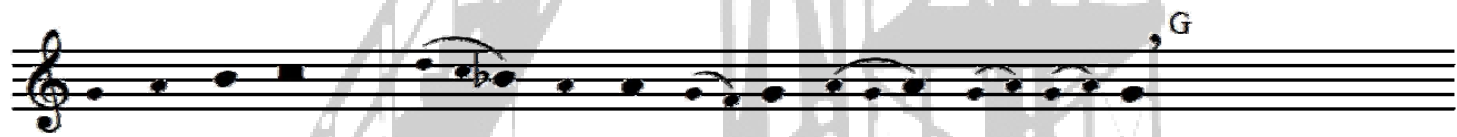

voy e - ran - tc en mi des - ti - no

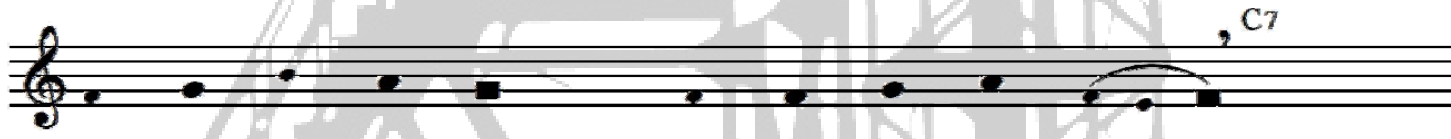

por mo po - der - te en - con - trar

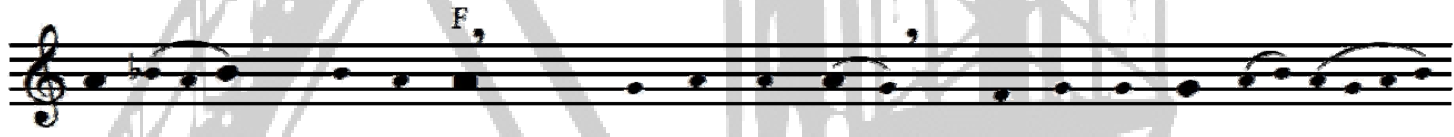

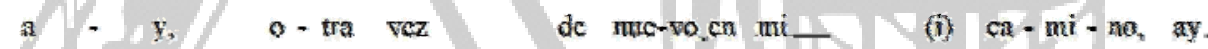

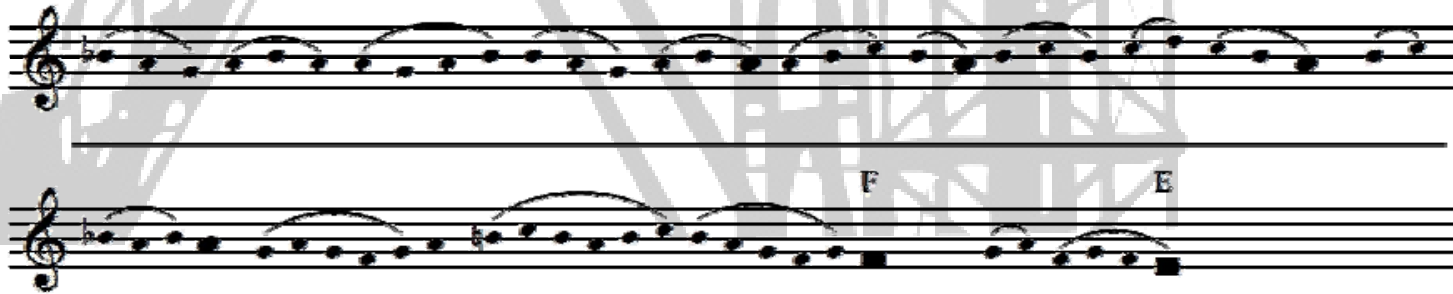

Aos: F. Ortega 